\title{
Exploring the reaction of multifunctional allylic bromides with $N, S$ - dinucleophiles: isothiuronium salts and analogs as useful motifs to assemble the 1,3-thiazine core
}

\author{
Marcus M. Sá, ${ }^{\mathrm{a}, *}$ Misael Ferreira, ${ }^{\mathrm{a}}$ Adailton J. Bortoluzzi, ${ }^{\mathrm{a}}$ Luciano Fernandes, ${ }^{\mathrm{b}}$ and Silvio \\ Cunha ${ }^{c}$ \\ ${ }^{a}$ Departamento de Química, Universidade Federal de Santa Catarina, Florianópolis, SC 88040- \\ 900, Brazil \\ ${ }^{b}$ Programa de Pós-Graduação em Biotecnologia e Recursos Naturais da Amazônia, \\ Universidade do Estado do Amazonas (UEA), Manaus, AM 69065-001, Brazil \\ 'Instituto de Química, Universidade Federal da Bahia, Campus de Ondina, Salvador, BA 40170- \\ 290, Brazil \\ E-mail: $\underline{m s a @ q m c . u f s c . b r}$
}

DOI: http://dx.doi.org/10.3998/ark.5550190.0011.b24

\begin{abstract}
The reactivity profile of allylic bromides (derived from the Morita-Baylis-Hillman reaction) towards thiourea derivatives and further transformations of the resulting isothiuronium bromides are described. Isothiuronium salts, prepared in near quantitative yields, undergo a selective acetylation or a base-promoted intramolecular cyclization to give 2-amino-1,3-thiazin-4-ones in good overall yields. Besides the simplicity of the reaction, conditions, and purification steps, the methods presented here furnished high-purity products. The structural characterization of representative compounds was unequivocally confirmed by X-ray diffraction analysis.
\end{abstract}

Keywords: Allylic bromide, isothiuronium salt, 1,3-thiazinone, aqueous solvent

\section{Introduction}

Isothiuronium salts have attracted the attention of the scientific community due to their unique chemical and biological properties. ${ }^{1}$ They have been explored as prodrugs of the alcoholdeterrent cyanamide, ${ }^{2}$ as agonists of GABA-type receptors, ${ }^{3}$ as local anesthesiophores, ${ }^{4}$ and as cationic detergents for the template-assisted assembly of plasmid DNA into stable nanomeric particles. ${ }^{5}$ Isothiuronium-containing molecules are also widely employed in the selective recognition of anions, ${ }^{6}$ particularly oxo-anions such as phosphates, sulfates and carboxylates. ${ }^{7}$ Isothiuronium salts are typically obtained through the displacement reaction of alkyl halides with thiourea and serve as convenient starting materials for the preparation of thiols due to their 
propensity to undergo cleavage of the amidino group by base-mediated solvolysis (Scheme 1a). ${ }^{8}$ It is known that the rate of the cleavage of the isothiuronium group is highly $\mathrm{pH}$-dependent and occurs very fast even under mild alkaline conditions. ${ }^{5}$ However, the fate of the isothiuronium salt as an electrophile in aqueous alkaline medium can be dramatically changed if other competitive electrophilic sites are available. For instance, the well-studied synthesis of 2-aminothiazoles ${ }^{9}$ from $\alpha$-bromoketones and thiourea derivatives involves the intermediacy of reactive isothiuronium salts that undergo cyclization even in the absence of a base ${ }^{10}$ (Scheme $1 b$ ).

While five-membered rings can be made available using this methodology, the homologous cyclization to afford the 1,3-thiazine framework has been rather underexplored, studies being restricted to simple $\beta$-haloacids such as 3 -chloropropionic acid ${ }^{11}$ (Scheme 1c).

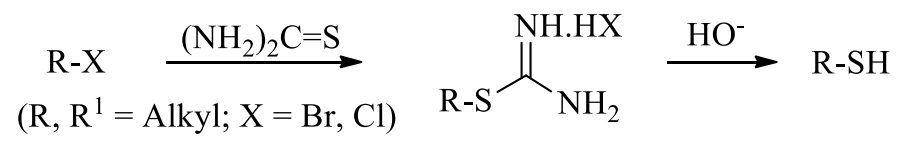

(1c)

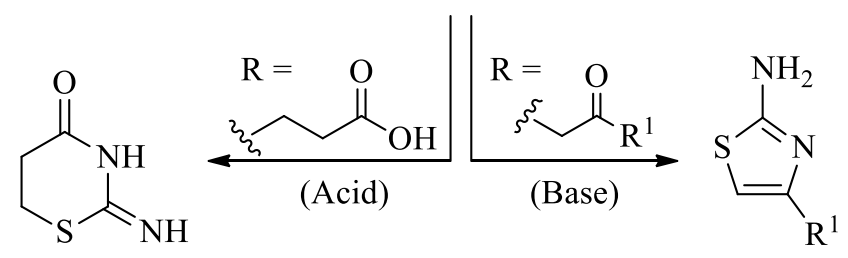

\section{Scheme 1}

As part of our research interest in synthetic transformations ${ }^{12}$ involving Morita-BaylisHillman adducts ${ }^{13} \mathbf{1}$, we recently reported that reaction of diverse allylic bromides 2 with thiourea in aqueous acetone and subsequent treatment of the intermediate isothiuronium salts with aqueous bicarbonate furnished 2-amino-1,3-thiazin-4-ones 3 in high yields under mild conditions $^{14}$ (Scheme 2).

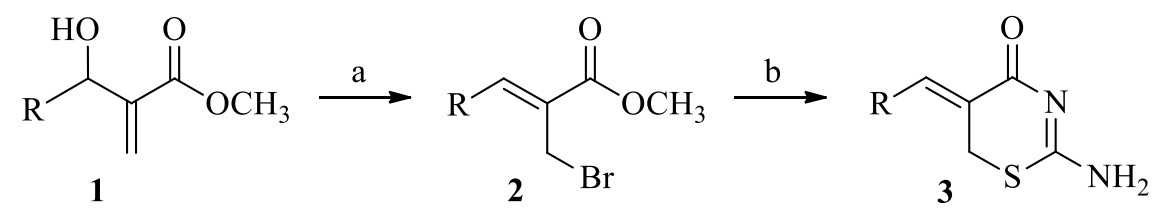

a: Refs. 12a-c,14; b: (i) $\left(\mathrm{NH}_{2}\right)_{2} \mathrm{C}=\mathrm{S}$, acetone: $\mathrm{H}_{2} \mathrm{O}, 25^{\circ} \mathrm{C}, 1 \mathrm{~h}$; (ii) sat. $\mathrm{NaHCO}_{3}$

\section{Scheme 2}

Herein, we present a full account of the preparation of isothiuronium salts and 2-amino-1,3thiazin-4-ones derived from Morita-Baylis-Hillman adducts, their selective acetylation in aqueous alkaline medium and further transformations wherein the thioureido unit plays a direct role. 


\section{Results and Discussion}

\section{Preparation of isothiuronium salts}

Treatment of allylic bromides 2a-h (readily available from the bromination of Morita-BaylisHillman adducts 1 with $\mathrm{LiBr}$ in acidic medium ${ }^{12 \mathrm{a}, \mathrm{c}}$ ) with 0.95 equiv of thiourea $4 \mathbf{a}$ (Figure 1) in aqueous acetone at room temperature furnished, in near quantitative yields, the corresponding isothiuronium salts 5a-h, which were easily isolated in pure form after an operationally simple work-up consisting of evaporating the solvent followed by trituration of the residue with a mixture of ether $/ \mathrm{CH}_{2} \mathrm{Cl}_{2}$ (Scheme 3 and Table 1). Salts $\mathbf{5 a - h}$ are stable crystalline solids that can be stored for months at $0{ }^{\circ} \mathrm{C}$ without any noticeable decomposition.<smiles>NC(N)=S</smiles>

$4 a$<smiles>NC(=S)Nc1ccccc1</smiles>

4b<smiles>[R]C(C)(C)NC(=S)NC(=O)c1ccccc1</smiles>

4d $\mathrm{R}=\mathrm{CH}_{3}$

Figure 1

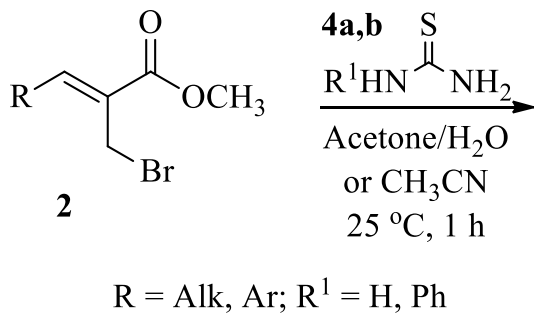<smiles>[R]C=C(CSC(=N)NBr)C(=O)OC</smiles>

5,6

\section{Scheme 3}

Table 1. Synthesis of isothiuronium salts 5 and $\mathbf{6}$

\begin{tabular}{ccccc}
\hline Entry & $\mathrm{R}$ & $\mathrm{R}^{1}$ & Product & Yield (\%) ${ }^{\mathrm{a}}$ \\
\hline 1 & $\mathrm{C}_{6} \mathrm{H}_{5}$ & $\mathrm{H}$ & $\mathbf{5 a}$ & 95 \\
2 & $4-\mathrm{CH}_{3} \mathrm{OC}_{6} \mathrm{H}_{4}$ & $\mathrm{H}$ & $\mathbf{5 b}$ & 94 \\
3 & $3,4-\left(\mathrm{OCH}_{2} \mathrm{O}\right) \mathrm{C}_{6} \mathrm{H}_{3}$ & $\mathrm{H}$ & $\mathbf{5 c}$ & 95 \\
4 & $4-\mathrm{NO}_{2} \mathrm{C}_{6} \mathrm{H}_{4}$ & $\mathrm{H}$ & $\mathbf{5 d}$ & 94 \\
5 & $2-\mathrm{ClC}_{6} \mathrm{H}_{4}$ & $\mathrm{H}$ & $\mathbf{5 e}$ & 91 \\
6 & $2-\mathrm{C}_{10} \mathrm{H}_{7}$ & $\mathrm{H}$ & $\mathbf{5 f}$ & 97 \\
7 & $\mathrm{CH}_{3}$ & $\mathrm{H}$ & $\mathbf{5 g}$ & 90 \\
8 & $\mathrm{CH}_{3} \mathrm{CH}_{2}$ & $\mathrm{H}$ & $\mathbf{5 h}$ & 92 \\
9 & $\mathrm{C}_{6} \mathrm{H}_{5}$ & $\mathrm{C}_{6} \mathrm{H}_{5}$ & $\mathbf{6 a}$ & 90 \\
10 & $4-\mathrm{CH}_{3} \mathrm{OC}_{6} \mathrm{H}_{4}$ & $\mathrm{C}_{6} \mathrm{H}_{5}$ & $\mathbf{6 b}$ & 91 \\
11 & $4-\mathrm{NO}_{2} \mathrm{C}_{6} \mathrm{H}_{4}$ & $\mathrm{C}_{6} \mathrm{H}_{5}$ & $\mathbf{6 d}$ & 92 \\
\hline
\end{tabular}

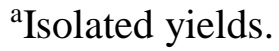


Considering that thiourea is an ambident nucleophile, either the sulfur or one of the nitrogen atoms is able to participate in a nucleophilic attack on one of the several electrophilic sites available in the allylic bromides 2 . Therefore, caution must be taken before assuming any product structure, especially due to the frequency with which the reactions of thiourea with electrophilic reagents have led to products whose structures have been subsequently revised. ${ }^{15}$ Besides their full spectroscopic characterization, mainly based upon the characteristic signals for the $\mathrm{SC}(=\mathrm{NH}) \mathrm{NH}$ and $\mathrm{CH}_{2} \mathrm{~S}$ groups ( $>170$ and $<30 \mathrm{ppm}$, respectively) in the ${ }^{13} \mathrm{C} \mathrm{NMR}$ spectra of all purified products, the structural elucidation of isothiuronium salts 5a-h was further confirmed by X-ray crystallographic analysis ${ }^{16}$ after the isolation of isothiuronium $\mathbf{5 b}$ as a single crystal from ethanol (Figure 2).

The reactivity profile of allylic bromides $\mathbf{2 a - h}$ was further studied with a non-symmetric S,Ndinucleophile, namely $N$-phenylthiourea $\mathbf{4 b}$. In this case, the use of aqueous acetone as the solvent system did not lead to acceptable results. However, a smooth conversion to the expected S-alkylated salts 6 was achieved in acetonitrile, which also facilitated the work-up because the products precipitated out and were separated by simple filtration, requiring no further purification (Table 1). In spite of the mild conditions and high yields obtained with thioureas $\mathbf{4 a}, \mathbf{b}$, allylic bromides 2 were not reactive in the presence of the N-benzoylated thioureas $\mathbf{4 c}$ or 4d (Figure 1), probably due to their lower nucleophilicity.

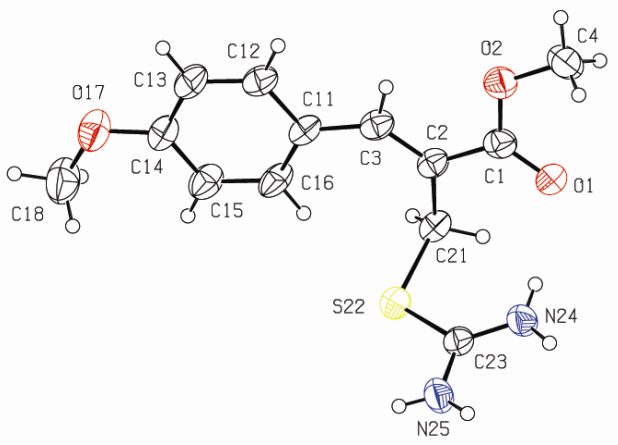

Figure 2. ORTEP plot of compound $\mathbf{5 b}$; ellipsoids are drawn at the $40 \%$ probability level.

\section{Acetylation of isothiuronium salts}

The unusual behavior of isothiuronium salts and their application as key intermediates in various transformations for the preparation of sulfur-containing compounds provided the motivation for further studies of the reactivity of allylic salts 5 and $\mathbf{6}$. Recently, mono- and diacylation of isothiuronium salts in basic medium has led to useful building blocks and $\mathrm{N}$ acylimidocarbamates of biological importance. ${ }^{17,18}$

Due to the high propensity of isothiuronium salts $\mathbf{5 a - h}$ to readily cyclize to 2 -amino-1,3thiazin-4-ones $\mathbf{3}$ in basic medium (see below), acetylation was carried out by mixing $\mathbf{5}$ and an excess of acetic anhydride in $\mathrm{CH}_{2} \mathrm{Cl}_{2}$ followed by quenching the mixture by the addition of aqueous $\mathrm{NaHCO}_{3}$. This resulted in a smooth transformation wherein a pre-formed isothioureido intermediate was intercepted by $\mathrm{Ac}_{2} \mathrm{O}$ to give N,N'-diacetylated products 7a-h in excellent yields 
(Scheme 4 and Table 2). No signal of cyclization products was detected. It is worth noting that the collection of the ${ }^{13} \mathrm{C}$ NMR spectroscopic data for the diacetylated products 7 in $\mathrm{CDCl}_{3}$ was not straightforward due to the absence of the characteristic signals for the acetyl groups at 25.0$29.0\left(\mathrm{CH}_{3}\right)$ and 179.0-185.0 $(\mathrm{C}=\mathrm{O})$ ppm. This suppression was probably a manifestation of stereo-electronic effects related to the nitrogen inversion barrier. ${ }^{19}$ Nevertheless, this problem was conveniently solved by acquiring all spectra in DMSO- $d_{6}$. A single crystal of $7 \mathbf{b}$ was collected from ethanol and was analyzed by X-ray methods, confirming the proposed structure (Figure 3a).<smiles>[R]C=C(CS/C(=N\c1ccccc1)NC(C)=O)C(=O)OC</smiles>

10

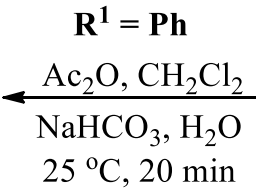

$25{ }^{\circ} \mathrm{C}, 20 \mathrm{~min}$

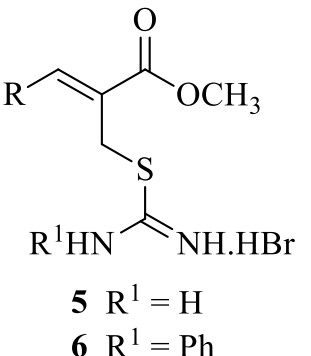

$6 \mathrm{R}^{1}=\mathrm{Ph}$

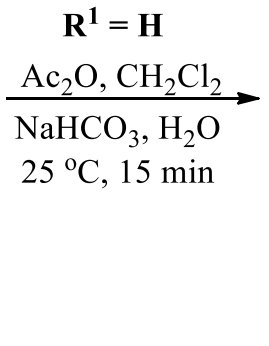

\section{Scheme 4}

Table 2. Synthesis of acetylated isothioureas 7 and $\mathbf{1 0}$

\begin{tabular}{ccccc}
\hline Entry & $\mathrm{R}$ & $\mathrm{R}^{1}$ & Product & Yield (\%) $)^{\mathrm{a}}$ \\
\hline 1 & $\mathrm{C}_{6} \mathrm{H}_{5}$ & $\mathrm{H}$ & $\mathbf{7 a}$ & 92 \\
2 & $4-\mathrm{CH}_{3} \mathrm{OC}_{6} \mathrm{H}_{4}$ & $\mathrm{H}$ & $\mathbf{7 b}$ & 97 \\
3 & $3,4-\left(\mathrm{OCH}_{2} \mathrm{O}\right) \mathrm{C}_{6} \mathrm{H}_{3}$ & $\mathrm{H}$ & $\mathbf{7 c}$ & 98 \\
4 & $4-\mathrm{NO}_{2} \mathrm{C}_{6} \mathrm{H}_{4}$ & $\mathrm{H}$ & $\mathbf{7 d}$ & 95 \\
5 & $2-\mathrm{ClC}_{6} \mathrm{H}_{4}$ & $\mathrm{H}$ & $\mathbf{7 e}$ & 91 \\
6 & $2-\mathrm{C}_{10} \mathrm{H}_{7}$ & $\mathrm{H}$ & $\mathbf{7 f}$ & 95 \\
7 & $\mathrm{CH}_{3}$ & $\mathrm{H}$ & $\mathbf{7 g}$ & 78 \\
8 & $\mathrm{CH}_{3} \mathrm{CH}_{2}$ & $\mathrm{H}$ & $\mathbf{7 h}$ & 81 \\
9 & $\mathrm{C}_{6} \mathrm{H}_{5}$ & $\mathrm{C}_{6} \mathrm{H}_{5}$ & $\mathbf{1 0 a}$ & $-{ }^{b}$ \\
10 & $4-\mathrm{CH}_{3} \mathrm{OC}_{6} \mathrm{H}_{4}$ & $\mathrm{C}_{6} \mathrm{H}_{5}$ & $\mathbf{1 0 b}$ & 65 \\
11 & $4-\mathrm{NO}_{2} \mathrm{C}_{6} \mathrm{H}_{4}$ & $\mathrm{C}_{6} \mathrm{H}_{5}$ & $\mathbf{1 0 d}$ & 63 \\
\hline
\end{tabular}

a Isolated yields for the reaction carried out in sat. $\mathrm{NaHCO}_{3} / \mathrm{CH}_{2} \mathrm{Cl}_{2}$.

${ }^{\mathrm{b}}$ Product 10a decomposed during attempted purification. 
(a)

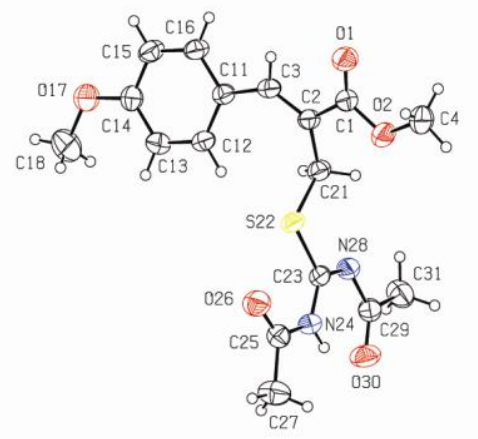

$7 \mathbf{b}$ (b)

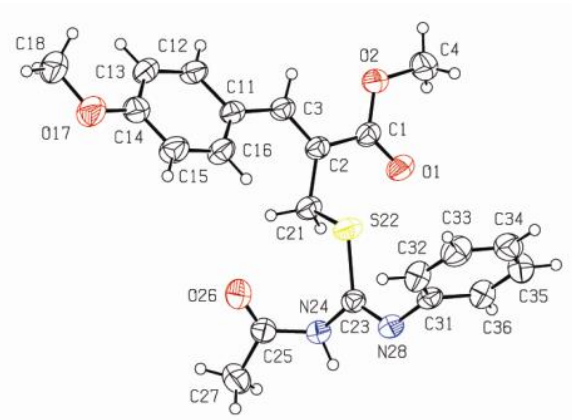

$10 \mathrm{~b}$ (c)

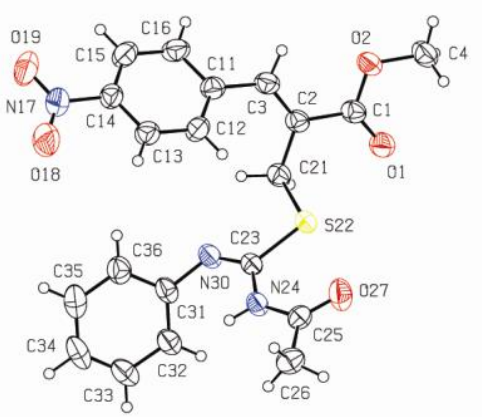

10d

Figure 3. ORTEP plot of compounds $7 \mathbf{b}(\mathrm{a}), \mathbf{1 0 b}(\mathrm{b})$ and $\mathbf{1 0 d}(\mathrm{c})$; ellipsoids are drawn at the $40 \%$ probability level.

Other reliable conditions for the diacetylation with $\mathrm{Ac}_{2} \mathrm{O}$ in basic medium include the use of pyridine in excess or a combination of $\mathrm{DBU}$ in $\mathrm{CH}_{3} \mathrm{CN}$, although the conditions with aqueous $\mathrm{NaHCO}_{3}$ gave cleaner reactions. On the other hand, employing a $2 \mathrm{M} \mathrm{NaOH}$ solution led not only to the formation of diacetylated products 7 but also the concurrent hydrolysis of the S-CN bond to give $e^{20,21}$ a mixture of thiol $\mathbf{8}$ and disulfide 9 as by-products in 10-25\% combined yield after chromatography (Scheme 5). However, efforts to increase the formation of the thiol/disulfide mixture by changing the reaction conditions, the work-up, or the starting materials 5 or 7 were unsuccessful.<smiles>[R]C=C(CSC(=N)N)C(=O)OC</smiles><smiles>[R]C=C(CSC(=NC(C)=O)NC(C)=O)C(=O)OC</smiles>

$$
\mathrm{NaOH}, \mathrm{H}_{2} \mathrm{O} \downarrow \mathrm{Ac}_{2} \mathrm{O}
$$$$
\mathrm{NaOH}, \mathrm{H}_{2} \mathrm{O} \downarrow
$$

$$
\left[\begin{array}{l}
\mathrm{R} \\
\mathrm{SH} \\
\end{array}\right.
$$<smiles>[R]C=C(CSSCC(=C[R])C(=O)OC)C(=O)OC</smiles>

\section{Scheme 5}

Acetylation of $\mathrm{N}$-phenylisothiuronium salts 6 under the aqueous conditions described above $\left(\mathrm{Ac}_{2} \mathrm{O} / \mathrm{CH}_{2} \mathrm{Cl}_{2}-\mathrm{NaHCO}_{3} / \mathrm{H}_{2} \mathrm{O}\right)$ led to somewhat different results. In the three cases studied, the 
major product observed was the monoacetyl isothiourea 10 (Scheme 4 and Table 2, entries 9-11). The corresponding 4-methoxy- and 4-nitro-substituted isothioureas 10b and 10d were easily separated from the unidentified minor by-products by recrystallization from ethyl acetate or by chromatography. The unequivocal determination that the unsubstituted $\mathrm{NH}$ group was selectively acetylated and not the $\mathrm{N}$-aryl-substituted one was achieved by single crystal X-ray methods after recrystallization of each monoacetylated product $\mathbf{1 0 b}$ and $\mathbf{1 0 d}$ from ethyl acetate (Figure $3 \mathrm{~b}, \mathrm{c}$ ). Unfortunately, all attempts to purify the phenyl-substituted derivative 10a, either by crystallization or column chromatography, failed due to extensive decomposition. Other basic conditions were also tested without success.

Unexpectedly, running the acetylation of the nitro-substituted salt $\mathbf{6 d}$ with acetic anhydride under basic medium at room temperature for longer periods (3-15 days) allowed the formation of the rearranged thiourea 11d (Figure 4) in up to $31 \%$ yield, together with the expected monoacetylated isothiourea 10d as the major product ( $c a .60-68 \%$ yield). All spectral data are consistent with the proposed structure for the by-product 11d, mainly based upon the appearance of typical signals for the terminal olefinic moiety $\left(\mathrm{CH}_{2}=\right)$ at around 6.0-6.5 ppm in the ${ }^{1} \mathrm{H}$ NMR spectrum, as well as the existence of a pair of doublets $(J=8.4 \mathrm{~Hz})$, which establishes the connectivity between $\mathrm{C} 3-\mathrm{H}(6.78 \mathrm{ppm})$ and the $\mathrm{NH}$ group (12.64 ppm, $\mathrm{D}_{2} \mathrm{O}$-exchangeable). The unexpected aza-Morita-Baylis-Hillman adduct 11d may be formed by a 3,3-sigmatropic rearrangement of the monoacetylated isomer A (Fig. 4), which could be generated by a competitive acetylation of the isothiuronium salt $\mathbf{6 d}$ at the less preferred $\mathrm{N}$-phenyl site. Evidence for the formation of intermediate $\mathbf{A}$ was found in the ${ }^{1} \mathrm{H}$ and ${ }^{13} \mathrm{C}$ NMR analysis of the crude reaction in the early stages, although its isolation was not possible due to a low stability. In addition, all attempts to convert the major product 10d into the rearranged 11d (by a phenyl or acetyl group migration from one nitrogen atom to the other) failed, but further studies will be necessary to unravel the mechanistic process associated with the formation of by-product $\mathbf{1 1 d}$.
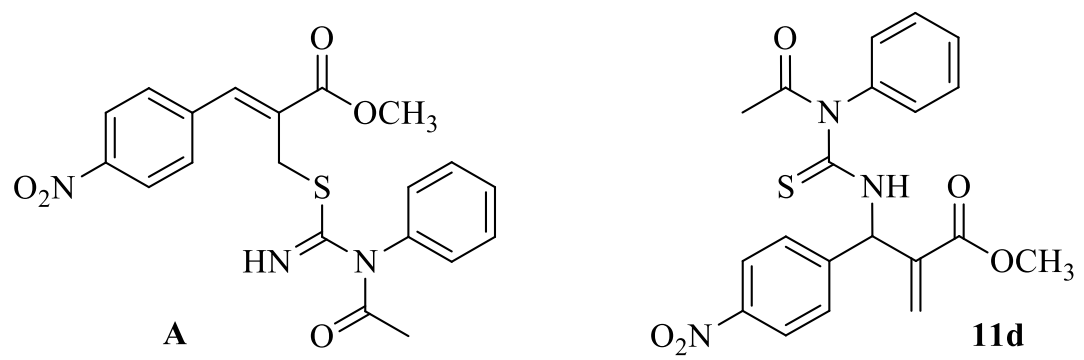

\section{Figure 4}

\section{Cyclization to thiazinones}

1,3-Thiazines constitute an important class of compounds in organic chemistry, and are common structural motifs in numerous bioactive molecules. ${ }^{22}$ Thiazines decorated with reactive functional groups, such as 2-amino-1,3-thiazin-4-ones, have recently attracted much attention due to their versatile applications as synthetic intermediates. ${ }^{23}$ According to our preliminary report, ${ }^{14}$ the 
one-step reaction of allylic bromides $2 \mathbf{a}$ with thiourea and subsequent addition of $\mathrm{NaHCO}_{3}$ as an acid scavenger gave 2-amino-1,3-thiazin-4-ones 3 as insoluble solids (Scheme 6). The results supported by NMR (taken in deuterated trifluoroacetic acid due to the very low solubility of thiazinones 3 in the majority of usual NMR solvents) were further validated by X-ray analysis after the isolation of 1,3-thiazin-4-one 3a as a single crystal. ${ }^{14}$ Therefore, in the absence of an external electrophile ( $\mathrm{such}$ as $\mathrm{Ac}_{2} \mathrm{O}$ ) an intramolecular attack of the nucleophilic isothioureido group on the carboxylate moiety takes place that ultimately produces the cyclized product $\mathbf{3}$ exclusively. Under these conditions, no product of alkaline hydrolysis (thiols, disulfides) was detected in the crude reactions (checked by NMR).

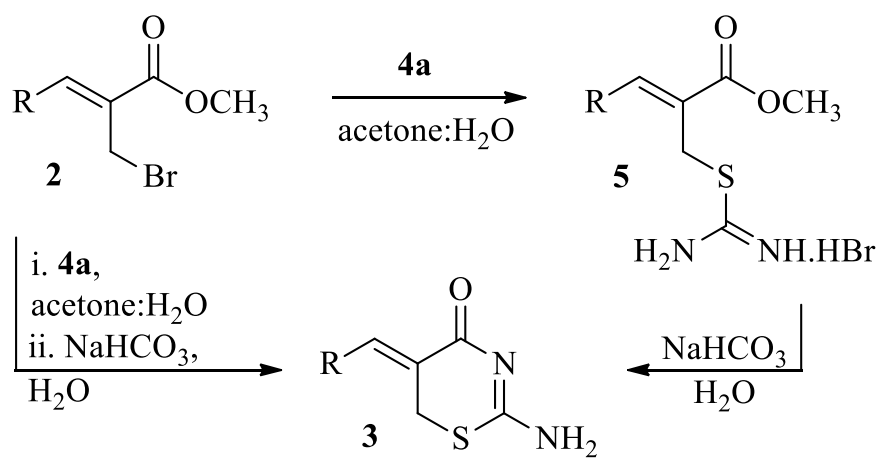

\section{Scheme 6}

This practical and straightforward reaction was extended to a variety of allylic bromides $\mathbf{2}$ and similar results were observed (Table 3). $\mathrm{NaHCO}_{3}$ was the base selected, but other bases such as $\mathrm{NaOH}$ and $\mathrm{Et}_{3} \mathrm{~N}$ were also suitable promoters of this transformation.

Although providing high yields and a simple work-up for most of the cases studied, the onestep procedure did not give a clean conversion to the naphthyl derivative $\mathbf{3 i}$ for which an acceptable match was not found in the elemental analysis. On the other hand, a two-step protocol, consisting of isolating the isothiuronium intermediate $\mathbf{5 i}$ prior to the basic treatment, not only produced the product $\mathbf{3 i}$ with analytical purity but also in higher overall yield (entry i). In a few other cases studied, the two-step procedure also proceeded cleanly to give the expected thiazinones $\mathbf{3}$ in high purity, although the yields were usually lower than in the one-step strategy.

Unfortunately, the presence of the phenyl groups in the N-phenylisothiuronium salts $\mathbf{6}$ was detrimental to the intramolecular cyclization process and no expected thiazinone was observed after several trials under a variety of basic procedures. Because of the high reactivity associated with N2-arylated 2-amino-1,3-thiazin-4-ones in aqueous medium, ${ }^{24}$ harsher conditions led to a complex mixture of products. 
Table 3. Synthesis of 1,3-thiazin-4-ones 3 from allylic bromides 2

Product

${ }^{a}$ Isolated yields from bromides 2 (one-step protocol); numbers in brackets refer to yields from isothiuronium salts $\mathbf{5}$ (two-step).

\section{Conclusions}

Reactions of allylic bromides 2 with thiourea (or $N$-phenylthiourea) in aqueous medium offer a smooth, efficient, and clean protocol to obtain multifunctionalized isothiuronium salts 5 (or 6) which were able to participate in selective acetylation reactions in the presence of $\mathrm{Ac}_{2} \mathrm{O}$ to give 
diacetylated products 7 (or monoacetylated derivatives $\mathbf{1 0}$ ), according to the substitution pattern of the thioureido framework. Isothiuronium salts $\mathbf{5}$ also participate in a base-promoted intramolecular cyclization to 2-amino-1,3-thiazin-4-ones 3. One of the most remarkable aspects of these methodologies is their simplicity in terms of setting up the reaction as well as the subsequent work-up and purification steps, affording in most cases high-purity products in nearly quantitative yields. The potential applicability of these multifunctionalized allylic products derived from the Morita-Baylis-Hillman reaction in further synthetic transformations is currently under research.

\section{Experimental Section}

General. All chemicals were of reagent grade and were used as received. Melting points were determined using a Microquímica MQPF301 apparatus and are uncorrected. Infrared spectra were acquired with a Perkin-Elmer FT-IR 1600 spectrometer (range 4000-400 cm ${ }^{-1}$ ) using $\mathrm{KBr}$ for solids and film for liquid samples. ${ }^{1} \mathrm{H}$ NMR $(400 \mathrm{MHz})$ and ${ }^{13} \mathrm{C}$ NMR (100 MHz, fully decoupled) spectra were recorded with a Varian AS-400 spectrometer. Samples were prepared in an appropriate deuterated solvent (DMSO- $d_{6}, \mathrm{CDCl}_{3}, \mathrm{D}_{2} \mathrm{O}$, or TFA- $d_{1}$ ). Chemical shifts are reported in parts per million $(\delta)$. Coupling constants $(J)$ are measured in Hertz $(\mathrm{Hz})$ and coupling patterns are designated as s (singlet); d (doublet); t (triplet); q (quartet); m (multiplet); brs (broad signal). X-ray analysis was carried out with an automatic diffractometer for monocrystals ENRAF NONIUS CAD-4. Elemental analyses were conducted in a CHNS-O Carlo Erba EA1110 by UFSC-Central Analítica, Departamento de Química, Florianópolis, SC, Brazil. Purifications by column chromatography were performed with silica gel (Aldrich, 100-200 mesh particle size). The allylic bromides $2^{12 \mathrm{a}-\mathrm{c}}$ and thiourea derivatives ${ }^{25} \mathbf{4 b}, \mathbf{4 c}$ and $\mathbf{4 d}$ were prepared according to the described methods. Detailed characterization of thiazin-4-ones $\mathbf{3 a}, \mathbf{3 g}$ and $\mathbf{3 j}$ was previously presented. ${ }^{14}$

\section{Typical procedure for the synthesis of isothiuronium bromides (5)}

To a stirred solution of allylic bromide $2(1.0 \mathrm{mmol})$ in $5.0 \mathrm{~mL}$ of acetone/ $\mathrm{H}_{2} \mathrm{O}(4: 1 \mathrm{v} / \mathrm{v})$ at $25^{\circ} \mathrm{C}$ was added $0.95 \mathrm{mmol}$ of thiourea. After stirring for $1 \mathrm{~h}$, the solution was concentrated under reduced pressure and the resulting solid was crushed with ethyl ether/ $\mathrm{CH}_{2} \mathrm{Cl}_{2}$ (4:1) and filtered to give pure isothiuronium salt $\mathbf{5}$.

Methyl ( $Z$ )-2-(isothioureidomethyl)-3-phenyl-2-propenoate hydrobromide (5a). White solid, mp 156.0-157.5 ${ }^{\circ} \mathrm{C}$; IR (KBr) $v_{\max } / \mathrm{cm}^{-1}: 3272,3172,3061,2723,1707,1628,1445,1272,1219$, 1084, 762. ${ }^{1} \mathrm{H}$ NMR (400 MHz, D $\left.2 \mathrm{O}\right): \delta 3.70$ (s, 3H), 4.08 (s, 2H), 7.30-7.35 (m, 5H), 7.81 (s, $1 \mathrm{H}) .{ }^{13} \mathrm{C}$ NMR $\left(100 \mathrm{MHz}, \mathrm{D}_{2} \mathrm{O}, \mathrm{DMSO}-d_{6}\right.$ as internal standard): $\delta 30.4\left(\mathrm{CH}_{2}\right), 54.5\left(\mathrm{OCH}_{3}\right)$, 126.0 (C), 130.6 (2 x CH), $130.9(2 \times \mathrm{CH}), 131.7(\mathrm{CH}), 135.0(\mathrm{C}), 146.8$ (=CH), 170.0 (C), 171.9 (C); Anal. Calcd for $\mathrm{C}_{12} \mathrm{H}_{15} \mathrm{BrN}_{2} \mathrm{O}_{2} \mathrm{~S}$ (\%): C, 43.51; H, 4.56; N, 8.46; S, 9.68. Found: C, 43.26; H, 4.65; N, 8.38; S, 9.28. 
Methyl (Z)-2-(isothioureidomethyl)-3-(4-methoxyphenyl)-2-propenoate hydrobromide (5b). White solid, mp 157.0-159.0 ${ }^{\circ} \mathrm{C}$; IR (KBr) $v_{\max } / \mathrm{cm}^{-1}: 3408,3331,3265,3048,2956,2711,1712$, 1639, 1598, 1514, 1437, 1265, 1174, 1076, 702; ${ }^{1} \mathrm{H}$ NMR (400 MHz, D $\left.2 \mathrm{O}\right): \delta 3.70$ (s, 3H), 3.71 $(\mathrm{s}, 3 \mathrm{H}), 4.11(\mathrm{~s}, 2 \mathrm{H}), 6.89(\mathrm{~d}, J=8.7 \mathrm{~Hz}, 2 \mathrm{H}), 7.27(\mathrm{~d}, J=8.7 \mathrm{~Hz}, 2 \mathrm{H}), 7.69(\mathrm{~s}, 1 \mathrm{H}) ;{ }^{13} \mathrm{C} \mathrm{NMR}$ (100 MHz, D $2 \mathrm{O}$, DMSO- $d_{6}$ as internal standard): $\delta 30.6\left(\mathrm{CH}_{2}\right), 54.4\left(\mathrm{OCH}_{3}\right), 57.0\left(\mathrm{OCH}_{3}\right), 116.1$ (2 x CH), $123.2(\mathrm{C}), 127.7(\mathrm{C}), 133.5(2 \times \mathrm{CH}), 146.6$ (=CH), $162.0(\mathrm{C}), 170.5(\mathrm{C}), 172.2(\mathrm{C})$; Anal. Calcd for $\mathrm{C}_{13} \mathrm{H}_{17} \mathrm{BrN}_{2} \mathrm{O}_{3} \mathrm{~S}(\%)$ : C, 43.22; H, 4.74; N, 7.75; S, 8.88. Found: C, 42.99; H, $4.63 ; \mathrm{N}, 7.77 ; \mathrm{S}, 8.86$.

Methyl

(Z)-2-(isothioureidomethyl)-3-(3,4-methylenedioxyphenyl)-2-propenoate hydrobromide (5c). Yellow solid, mp 177.0-178.5 ${ }^{\circ} \mathrm{C}$; IR $(\mathrm{KBr}) v_{\max } / \mathrm{cm}^{-1}: 3179,3049,2736$, 1669, 1596, 1498, 1444, 1295, 1250, 1032, 676; ${ }^{1} \mathrm{H}$ NMR (400 MHz, D $\left.2 \mathrm{O}\right): \delta 3.70$ (s, 3H), 4.12 (s, 2H), 5.89 (s, 2H), 6.80-6.87 (m, 3H), $7.68(\mathrm{~s}, 1 \mathrm{H}) ;{ }^{13} \mathrm{C}$ NMR (100 MHz, D $2 \mathrm{O}$, DMSO-d 6 as internal standard): $\delta 30.4\left(\mathrm{CH}_{2}\right), 54.4\left(\mathrm{OCH}_{3}\right), 103.4\left(\mathrm{CH}_{2}\right), 110.5(\mathrm{CH}), 110.6(\mathrm{CH}), 123.5(\mathrm{C})$, $127.2(\mathrm{CH}), 128.8(\mathrm{C}), 146.5(=\mathrm{CH}), 149.4(\mathrm{C}), 150.5(\mathrm{C}), 170.1(\mathrm{C}), 171.9(\mathrm{C})$; Anal. Calcd for $\mathrm{C}_{13} \mathrm{H}_{15} \mathrm{BrN}_{2} \mathrm{O}_{4} \mathrm{~S}(\%)$ : C, 41.61; H, 4.03; N, 7.47; S, 8.55. Found: C, 41.54; H, 3.93; N, 7.42; S, 8.59 .

Methyl (Z)-2-(isothioureidomethyl)-3-(4-nitrophenyl)-2-propenoate hydrobromide (5d). Yellow solid, mp 187.0-189.0 ${ }^{\circ} \mathrm{C}$; IR $(\mathrm{KBr}) v_{\max } / \mathrm{cm}^{-1}$ : 3477, 3413, 3185, 3056, 2725, 1719 , 1656, 1597, 1512, 1429, 1339, 1256, 1216, 1076, 692; ${ }^{1} \mathrm{H}$ NMR (400 MHz, D $\left.2 \mathrm{O}\right): \delta 3.73$ (s, $\left.3 \mathrm{H}\right)$, $4.05(\mathrm{~s}, 2 \mathrm{H}), 7.46(\mathrm{~d}, J=8.5 \mathrm{~Hz}, 2 \mathrm{H}), 7.87(\mathrm{~s}, 1 \mathrm{H}), 8.15(\mathrm{~d}, J=8.5 \mathrm{~Hz}, 2 \mathrm{H}) ;{ }^{13} \mathrm{C} \mathrm{NMR}(100$ $\mathrm{MHz}, \mathrm{D}_{2} \mathrm{O}$, DMSO- $d_{6}$ as internal standard): $\delta 30.2\left(\mathrm{CH}_{2}\right), 54.6\left(\mathrm{OCH}_{3}\right), 125.6(2 \mathrm{x} \mathrm{CH}), 129.7$ (C), $131.6(2 \times \mathrm{CH}), 142.0(\mathrm{C}), 144.1$ (=CH), 149.2 (C), 169.4 (C), 171.5 (C); Anal. Calcd for $\mathrm{C}_{12} \mathrm{H}_{14} \mathrm{BrN}_{3} \mathrm{O}_{4} \mathrm{~S}(\%)$ : C, 38.31; H, 3.75; N, 11.17; S, 8.52. Found: C, 38.42; H, 3.53; N, 11.10; S, 8.75 .

Methyl (Z)-3-(2-chlorophenyl)-2-(isothioureidomethyl)-2-propenoate hydrobromide (5e). White solid, mp 84.0-87.0 ${ }^{\circ} \mathrm{C}$; IR (KBr) $v_{\max } / \mathrm{cm}^{-1}: 3591,3415,3244,3068,2740,1704,1661$, 1634, 1441, 1302, 1259, 1213, 1168, 1078, 778; ${ }^{1} \mathrm{H}$ NMR (400 MHz, D $\left.2 \mathrm{O}\right): \delta 3.72$ (s, 3H), 3.95 $(\mathrm{s}, 2 \mathrm{H}), 7.20-7.40(\mathrm{~m}, 4 \mathrm{H}), 7.82(\mathrm{~s}, 1 \mathrm{H}) ;{ }^{13} \mathrm{C} \mathrm{NMR}\left(100 \mathrm{MHz}, \mathrm{D}_{2} \mathrm{O}\right.$, DMSO- $d_{6}$ as internal standard): $\delta 30.3\left(\mathrm{CH}_{2}\right), 54.5\left(\mathrm{OCH}_{3}\right), 129.0(\mathrm{CH}), 129.7(\mathrm{C}), 131.2(\mathrm{CH}), 131.3(\mathrm{CH}), 132.6$ $(\mathrm{CH}), 133.9$ (C), $134.7 \quad(\mathrm{C}), 143.2 \quad(=\mathrm{CH}), 169.2 \quad(\mathrm{C}), 171.2$ (C); Anal. Calcd for $\mathrm{C}_{12} \mathrm{H}_{14} \mathrm{BrClN}_{2} \mathrm{O}_{2} \mathrm{~S} . \mathrm{H}_{2} \mathrm{O}$ (\%): C, 37.56; H, 4.20; N, 7.30; S, 8.36. Found: C, 37.56; H, 4.19; N, 7.26; S, 8.29.

Methyl (Z)-2-(isothioureidomethyl)-3-(2-naphthyl)-2-propenoate hydrobromide (5f). White solid, mp 115.0-118.0 ${ }^{\circ} \mathrm{C}$; IR (KBr) $v_{\max } / \mathrm{cm}^{-1}: 3339,3182,2947,1687,1642,1617,1429,1267$, 1244, 1191, 760; ${ }^{1} \mathrm{H}$ NMR (400 MHz, DMSO-d6): $\delta 3.82$ (s, 3H), 4.38 (s, 2H), 7.58-7.67 (m, $3 \mathrm{H}), 7.95-8.00(\mathrm{~m}, 2 \mathrm{H}), 8.04-8.06(\mathrm{~m}, 2 \mathrm{H}), 8.12(\mathrm{~s}, 1 \mathrm{H}), 9.10-9.25$ (brs, 4H); ${ }^{13} \mathrm{C}$ NMR $(100$ MHz, DMSO-d $)): \delta 30.1\left(\mathrm{CH}_{2}\right), 53.7\left(\mathrm{OCH}_{3}\right), 125.3(\mathrm{C}), 127.2(\mathrm{CH}), 127.9(\mathrm{CH}), 128.6(\mathrm{CH})$, $128.7(\mathrm{CH}), 129.5$ (2 x CH), $131.0(\mathrm{CH}), 132.0(\mathrm{C}), 133.6(\mathrm{C}), 134.1(\mathrm{C}), 144.9$ (=CH), 167.3 (C), 170.3 (C); Anal. Calcd for $\mathrm{C}_{16} \mathrm{H}_{17} \mathrm{BrN}_{2} \mathrm{O}_{2} \mathrm{~S} . \mathrm{H}_{2} \mathrm{O}(\%)$ : C, 48.13; H, 4.80; N, 7.02; S, 8.03. Found: C, 48.23; H, 4.70; N, 7.00; S, 8.00. 
Methyl (Z)-2-(isothioureidomethyl)-2-butenoate hydrobromide (5g). White solid, mp 101.5$103.0^{\circ} \mathrm{C}$; IR (KBr) $v_{\max } / \mathrm{cm}^{-1}: 3266,3070,2695,1729,1648,1438,1281,1197,1183,1057,766$, 690; ${ }^{1} \mathrm{H}$ NMR (400 MHz, D $\left.2 \mathrm{O}\right): \delta 1.84(\mathrm{~d}, J=7.3 \mathrm{~Hz}, 3 \mathrm{H}), 3.68$ (s, 3H), 4.02 (s, 2H), 7.13 (q, $J$ $=7.3 \mathrm{~Hz}, 1 \mathrm{H}) ;{ }^{13} \mathrm{C}$ NMR $\left(100 \mathrm{MHz}, \mathrm{D}_{2} \mathrm{O}, \mathrm{DMSO}-d_{6}\right.$ as internal standard $): \delta 15.9\left(\mathrm{CH}_{3}\right), 28.5$ $\left(\mathrm{CH}_{2}\right), 54.0\left(\mathrm{OCH}_{3}\right), 126.8(\mathrm{C}), 147.9(=\mathrm{CH}), 169.1(\mathrm{C}), 171.9(\mathrm{C}) ;$ Anal. Calcd for $\mathrm{C}_{7} \mathrm{H}_{13} \mathrm{BrN}_{2} \mathrm{O}_{2} \mathrm{~S}(\%)$ : C, 31.24; H, 4.87; N, 10.41; S, 11.91. Found: C, 31.22; H, 4.84; N, 10.30; S, 12.24 .

Methyl (Z)-2-(isothioureidomethyl)-2-pentenoate hydrobromide (5h). Brown solid, mp 145.5-148.0 ${ }^{\circ} \mathrm{C}$; IR (KBr) $v_{\max } / \mathrm{cm}^{-1}: 3294,3249$, 3098, 2717, 1703, 1648, 1631, 1429, 1359, 1295, 1256, 1197, 1144, 635; ${ }^{1} \mathrm{H}$ NMR (400 MHz, D $\left.2 \mathrm{O}\right): \delta 0.94(\mathrm{t}, J=7.5 \mathrm{~Hz}, 3 \mathrm{H}), 2.21$ (dq, $J$ $=7.5$ and $7.8 \mathrm{~Hz}, 2 \mathrm{H}), 3.68(\mathrm{~s}, 3 \mathrm{H}), 3.99(\mathrm{~s}, 2 \mathrm{H}), 7.03(\mathrm{t}, J=7.8 \mathrm{~Hz}, 1 \mathrm{H}) ;{ }^{13} \mathrm{C} \mathrm{NMR}(100 \mathrm{MHz}$, $\mathrm{D}_{2} \mathrm{O}, \mathrm{DMSO}-d_{6}$ as internal standard): $\delta 13.8\left(\mathrm{CH}_{3}\right), 23.7\left(\mathrm{CH}_{2}\right), 28.8\left(\mathrm{CH}_{2}\right), 54.1\left(\mathrm{OCH}_{3}\right), 125.4$ (C), 154.2 (=CH), 169.7 (C), 172.1 (C); Anal. Calcd for $\mathrm{C}_{8} \mathrm{H}_{15} \mathrm{BrN}_{2} \mathrm{O}_{2} \mathrm{~S}$ (\%): C, 33.93; H, 5.34; N, 9.89; S, 11.32. Found: C, 33.71; H, 5.25; N, 10.02; S, 11.17.

\section{Typical procedure for the synthesis of $N$-phenylisothiuronium bromides (6)}

To a stirred solution of allylic bromide $2(1.0 \mathrm{mmol})$ in $5.0 \mathrm{~mL}$ of acetonitrile at $25{ }^{\circ} \mathrm{C}$ was added $N$-phenylthiourea $(0.95 \mathrm{mmol})$. After stirring for $1 \mathrm{~h}$, the insoluble solid formed was separated by filtration and washed with acetonitrile to give pure $N$-substituted isothiuronium salts 6.

Methyl ( $Z$ )-3-phenyl-2-[( $\boldsymbol{N}$-phenylisothioureido)methyl]-2-propenoate hydrobromide (6a). White solid, mp 174.5-177.0 ${ }^{\circ} \mathrm{C}$; IR (KBr) $v_{\max } / \mathrm{cm}^{-1}: 3440,3260,2991,2857,2767,1709,1645$, $1625,1563,1450,1282,1206,777,755,696 ;{ }^{1} \mathrm{H}$ NMR (400 MHz, DMSO- $\left.d_{6}\right): \delta 3.81$ (s, 3H), 4.39 (s, 2H), 7.30-7.55 (m, 10H), 7.90 (s, 1H), 9.57 (brs, NH), 11.49 (brs, NH); ${ }^{13} \mathrm{C} \mathrm{NMR} \mathrm{(100}$ MHz, DMSO-d $): \delta 31.0\left(\mathrm{CH}_{2}\right), 53.6\left(\mathrm{OCH}_{3}\right), 125.5(\mathrm{C}), 126.1(2 \mathrm{x} \mathrm{CH}), 129.2(\mathrm{CH}), 130.0(2 \mathrm{x}$ $\mathrm{CH}), 130.6$ (2 x CH), 130.9 (2 x CH), $131.0(\mathrm{CH}), 134.4(\mathrm{C}), 135.9(\mathrm{C}), 144.8$ (=CH), 167.3 (C), 168.2 (C); Anal. Calcd. for $\mathrm{C}_{18} \mathrm{H}_{19} \mathrm{BrN}_{2} \mathrm{O}_{2} \mathrm{~S}$ (\%): C, 53.08; H, 4.70; N, 6.88; S, 7.87. Found: C, $53.04 ; \mathrm{H}, 4.95 ; \mathrm{N}, 6.81 ; \mathrm{S}, 7.87$.

Methyl ( $Z$ )-3-(4-methoxyphenyl)-2-[( $N$-phenylisothioureido)methyl]-2-propenoate hydrobromide (6b). White solid, mp 193.0-195.5 ${ }^{\circ} \mathrm{C}$; IR (KBr) $v_{\max } / \mathrm{cm}^{-1}: 3276,3100,1712,1627,1601,1572$, 1510, 1432, 1255, 1170, 835; ${ }^{1} \mathrm{H}$ NMR (400 MHz, DMSO-d $)$ : $\delta 3.78$ (s, 3H), $3.80(\mathrm{~s}, 3 \mathrm{H}), 4.46$ (s, 2H), $7.06(\mathrm{~d}, J=8.7 \mathrm{~Hz}, 2 \mathrm{H}), 7.33-7.42(\mathrm{~m}, 3 \mathrm{H}), 7.48-7.60(\mathrm{~m}, 4 \mathrm{H}), 7.84(\mathrm{~s}, 1 \mathrm{H}), 9.60$ (brs, $\mathrm{NH}), 11.50$ (brs, NH); ${ }^{13} \mathrm{C}$ NMR (100 MHz, DMSO-d $)$ : $\delta 31.2\left(\mathrm{CH}_{2}\right), 53.5\left(\mathrm{OCH}_{3}\right), 56.4$ $\left(\mathrm{OCH}_{3}\right), 115.6(2 \times \mathrm{CH}), 122.2(\mathrm{C}), 126.2(2 \times \mathrm{CH}), 126.6(\mathrm{C}), 129.2(\mathrm{CH}), 130.9(2 \times \mathrm{CH})$, $133.1(2 \times \mathrm{CH}), 135.9(\mathrm{C}), 144.6(=\mathrm{CH}), 161.8(\mathrm{C}), 167.6(\mathrm{C}), 168.3(\mathrm{C})$; Anal. Calcd. for $\mathrm{C}_{19} \mathrm{H}_{21} \mathrm{BrN}_{2} \mathrm{O}_{3} \mathrm{~S}(\%)$ : C, 52.18; H, 4.84; N, 6.41; S, 7.33. Found: C, 52.36; H, 4.82; N, 6.34; S, 7.78 .

Methyl (Z)-3-(4-nitrophenyl)-2-[( $N$-phenylisothioureido)methyl]-2-propenoate hydrobromide (6d). White solid, mp 199.0-201.0 ${ }^{\circ} \mathrm{C}$; IR (KBr) $v_{\max } / \mathrm{cm}^{-1}: 3254,3100,1723,1631,1590,1576$, 1517, 1436, 1345, 1277, 1207; ${ }^{1} \mathrm{H}$ NMR (400 MHz, DMSO-d $)_{\text {): } \delta} 3.81$ (s, 3H), 4.37 (s, 2H), 7.27 $(\mathrm{d}, J=7.7 \mathrm{~Hz}, 2 \mathrm{H}), 7.38(\mathrm{t}, J=7.7 \mathrm{~Hz}, 1 \mathrm{H}), 7.48(\mathrm{t}, J=7.7 \mathrm{~Hz}, 2 \mathrm{H}), 7.76(\mathrm{~d}, J=8.8 \mathrm{~Hz}, 2 \mathrm{H})$, 
7.96 (s, 1H), 8.26 (d, $J=8.8 \mathrm{~Hz}, 2 \mathrm{H}), 9.55$ (brs, NH), 11.40 (brs, NH); ${ }^{13} \mathrm{C} \mathrm{NMR} \mathrm{(100} \mathrm{MHz,}$ DMSO-d $\left.)_{6}\right): \delta 30.5\left(\mathrm{CH}_{2}\right), 53.8\left(\mathrm{OCH}_{3}\right), 124.9(2 \times \mathrm{CH}), 125.7(2 \times \mathrm{CH}), 129.1(\mathrm{CH}), 129.4(\mathrm{C})$, $130.8(2 \times \mathrm{CH}), 131.6$ (2 x CH), 135.9 (C), 141.1 (C), 142.0 (=CH), $148.4(\mathrm{C}), 166.8(\mathrm{C}), 167.4$ (C); Anal. Calcd. for $\mathrm{C}_{18} \mathrm{H}_{18} \mathrm{BrN}_{3} \mathrm{O}_{4} \mathrm{~S}(\%)$ : C, 47.80; H, 4.01; N, 9.29; S, 7.09. Found: C, 47.96; H, 3.92; N, 9.15; S, 6.86.

\section{Typical procedure for the acetylation of isothiuronium bromides (5)}

To a stirred suspension of isothiuronium bromide $5(1.0 \mathrm{mmol})$ in $3.0 \mathrm{~mL}$ of $\mathrm{CH}_{2} \mathrm{Cl}_{2}$ at $25^{\circ} \mathrm{C}$ was added acetic anhydride $(3.0 \mathrm{mmol})$ followed by sat. $\mathrm{NaHCO}_{3}(3.0 \mathrm{~mL})$. After stirring for 15 min, the final mixture was diluted with $\mathrm{CH}_{2} \mathrm{Cl}_{2}$ and the organic extract was washed with $\mathrm{H}_{2} \mathrm{O}$ and brine, dried over $\mathrm{Na}_{2} \mathrm{SO}_{4}$, filtered and concentrated under reduced pressure to give the corresponding acetylated products 7 .

Methyl (Z)-2-[( $N, N^{\prime}$-diacetylisothioureido)methyl]-3-phenyl-2-propenoate (7a). White solid, mp 101.0-104.0 ${ }^{\circ} \mathrm{C}$; IR (KBr) $v_{\max } / \mathrm{cm}^{-1}: 3429,3014,2952,1723,1709,1614,1541,1435,1370$, 1258, 1213, 1188, 1152, 766; ${ }^{1} \mathrm{H}$ NMR (400 MHz, DMSO- $d_{6}$ ): $\delta 1.90$ (brs, 3H), 1.95 (brs, 3H), $3.76(\mathrm{~s}, 3 \mathrm{H}), 4.02(\mathrm{~s}, 2 \mathrm{H}), 7.42-7.51(\mathrm{~m}, 5 \mathrm{H}), 7.75(\mathrm{~s}, 1 \mathrm{H}), 10.95$ (brs, $1 \mathrm{H}) ;{ }^{13} \mathrm{C} \mathrm{NMR}(100 \mathrm{MHz}$, DMSO-d $): \delta 24.4\left(\mathrm{CH}_{3}\right), 27.0\left(\mathrm{CH}_{3}\right), 29.1\left(\mathrm{CH}_{2}\right), 53.4\left(\mathrm{OCH}_{3}\right), 127.6(\mathrm{C}), 129.8(2 \times \mathrm{CH})$, $130.4(\mathrm{CH}), 130.6$ (2 x CH), 135.2 (C), 142.6 (=CH), 152.9 (C), 167.9 (C), 169.8 (C), 181.0 (C); Anal. Calcd for $\mathrm{C}_{16} \mathrm{H}_{18} \mathrm{~N}_{2} \mathrm{O}_{4} \mathrm{~S}(\%)$ : C, 57.47; H, 5.43; N, 8.38; S, 9.59. Found: C, 57.87; H, 5.41; N, 8.42; S, 9.81 .

Methyl (Z)-2-[( $N, N^{\prime}$-diacetylisothioureido)methyl]-3-(4-methoxyphenyl)-2-propenoate (7b). White solid, mp 140.5-142.5 ${ }^{\circ} \mathrm{C}$; IR (KBr) $v_{\max } / \mathrm{cm}^{-1}: 3429,3014,2957,1723,1706,1619,1602$, 1538, 1438, 1384, 1275, 1261, 1177, 1152; ${ }^{1} \mathrm{H}$ NMR (400 MHz, DMSO-d6): $\delta 1.97$ (s, 6H), 3.74 (s, 3H), $3.78(\mathrm{~s}, 3 \mathrm{H}), 4.03(\mathrm{~s}, 2 \mathrm{H}), 7.01(\mathrm{~d}, J=8.5 \mathrm{~Hz}, 2 \mathrm{H}), 7.50(\mathrm{~d}, J=8.5 \mathrm{~Hz}, 2 \mathrm{H}), 7.70$ (s, 1H), 10.98 (brs, $1 \mathrm{H}) ;{ }^{13} \mathrm{C}$ NMR (100 MHz, DMSO-d $): \delta 24.4\left(\mathrm{CH}_{3}\right), 27.2\left(\mathrm{CH}_{3}\right), 29.4\left(\mathrm{CH}_{2}\right)$, $53.2\left(\mathrm{OCH}_{3}\right), 56.3\left(\mathrm{OCH}_{3}\right), 115.3(2 \times \mathrm{CH}), 124.5(\mathrm{C}), 127.4(\mathrm{C}), 132.8(2 \times \mathrm{CH}), 142.7(=\mathrm{CH})$, 153.3 (C), 161.4 (C), 168.1 (C), 169.9 (C), 181.2 (C); Anal. Calcd for $\mathrm{C}_{17} \mathrm{H}_{20} \mathrm{~N}_{2} \mathrm{O}_{5} \mathrm{~S}$ (\%): C, 56.03; H, 5.53; N, 7.69; S, 8.80. Found: C, 55.93; H, 5.18; N, 7.52; S, 9.04.

Methyl (Z)-2-[( $N, N^{\prime}$-diacetylisothioureido)methyl]-3-(3,4-methylenedioxyphenyl)-2-propenoate (7c). White solid, mp 128.5-130.5 ${ }^{\circ} \mathrm{C}$; IR (KBr) $v_{\max } / \mathrm{cm}^{-1}: 3440,3294,2942,1723,1703,1642$, 1611, 1566, 1502, 1440, 1348, 1239, 1152; ${ }^{1} \mathrm{H}$ NMR (400 MHz, DMSO-d6): $\delta 1.97$ (s, 6H), 3.74 $(\mathrm{s}, 3 \mathrm{H}), 4.02(\mathrm{~s}, 2 \mathrm{H}), 6.07(\mathrm{~s}, 2 \mathrm{H}), 7.00(\mathrm{~d}, J=8.0 \mathrm{~Hz}, 1 \mathrm{H}), 7.06(\mathrm{~d}, J=8.0 \mathrm{~Hz}, 1 \mathrm{H}), 7.13(\mathrm{~s}$, 1H), 7.66 (s, 1H), 10.98 (brs, 1H); ${ }^{13} \mathrm{C}$ NMR (100 MHz, DMSO-d $)$ : $\delta 24.4\left(\mathrm{CH}_{3}\right), 27.1\left(\mathrm{CH}_{3}\right)$, $29.3\left(\mathrm{CH}_{2}\right), 53.3\left(\mathrm{OCH}_{3}\right), 102.6\left(\mathrm{CH}_{2}\right), 109.6(\mathrm{CH}), 110.3(\mathrm{CH}), 125.2(\mathrm{C}), 126.3(\mathrm{CH}), 129.0$ (C), 142.7 (=CH), 148.7 (C), 149.5 (C), 153.2 (C), 168.0 (C), 169.9 (C), 181.1 (C); Anal. Calcd for $\mathrm{C}_{17} \mathrm{H}_{18} \mathrm{~N}_{2} \mathrm{O}_{6} \mathrm{~S}(\%)$ : C, 53.96; H, 4.79; N, 7.40; S, 8.47. Found: C, 53.75; H, 4.76; N, 7.14; S, 8.66.

Methyl (Z)-2-[( $N, N^{\prime}$-diacetylisothioureido)methyl]-3-(4-nitrophenyl)-2-propenoate (7d). Yellowish solid, mp 142.0-143.5 ${ }^{\circ} \mathrm{C}$; IR (KBr) $v_{\max } / \mathrm{cm}^{-1}: 3422,3103,2952,1726,1707,1625$, $1542,1519,1342,1258,1230,1212,1188,1152,1068,850,755 ;{ }^{1} \mathrm{H}$ NMR (400 MHz, DMSO- 
$\left.d_{6}\right): \delta 1.80(\mathrm{~s}, 3 \mathrm{H}), 1.96(\mathrm{~s}, 3 \mathrm{H}), 3.81(\mathrm{~s}, 3 \mathrm{H}), 4.04(\mathrm{~s}, 2 \mathrm{H}), 7.75(\mathrm{~d}, J=8.0 \mathrm{~Hz}, 2 \mathrm{H}), 7.81(\mathrm{~s}, 1 \mathrm{H})$; 8.28 (d, $J=8.0 \mathrm{~Hz}, 2 \mathrm{H}), 10.92$ (brs, $1 \mathrm{H}) ;{ }^{13} \mathrm{C} \mathrm{NMR}\left(100 \mathrm{MHz}, \mathrm{DMSO}-d_{6}\right): \delta 24.4\left(\mathrm{CH}_{3}\right), 26.8$ $\left(\mathrm{CH}_{3}\right), 28.5\left(\mathrm{CH}_{2}\right), 53.6\left(\mathrm{OCH}_{3}\right), 124.6(2 \times \mathrm{CH}), 131.4(\mathrm{C}), 131.6(2 \times \mathrm{CH}), 139.8(\mathrm{C}), 142.0$ $(=\mathrm{CH}), 148.2(\mathrm{C}), 152.3(\mathrm{C}), 167.5(\mathrm{C}), 169.8(\mathrm{C}), 180.8(\mathrm{C})$; Anal. Calcd for $\mathrm{C}_{16} \mathrm{H}_{17} \mathrm{~N}_{3} \mathrm{O}_{6} \mathrm{~S}(\%)$ : C, 50.65; H, 4.52; N, 11.08; S, 8.45. Found: C, 50.95; H, 4.40; N, 10.81; S, 8.54.

Methyl (Z)-3-(2-chlorophenyl)-2-[( $N, N^{\prime}$-diacetylisothioureido)methyl]-2-propenoate (7e). White solid, $\mathrm{mp} 89.0-90.5^{\circ} \mathrm{C}$; IR (KBr) $v_{\max } / \mathrm{cm}^{-1}: 3434,3103,3019,2957,1726,1706,1622$, 1538, 1519, 1435, 1387, 1256, 1205, 1186, 1152, 758; ${ }^{1} \mathrm{H}$ NMR (400 MHz, DMSO-d6): $\delta 1.79$ (s, 3H), 1.94 (s, 3H), $3.78(\mathrm{~s}, 3 \mathrm{H}), 3.93(\mathrm{~s}, 2 \mathrm{H}), 7.39-7.57(\mathrm{~m}, 4 \mathrm{H}), 7.74(\mathrm{~s}, 1 \mathrm{H}), 10.88$ (brs, 1H); ${ }^{13} \mathrm{C}$ NMR (100 MHz, DMSO-d $)$ : $\delta 24.4\left(\mathrm{CH}_{3}\right), 26.9\left(\mathrm{CH}_{3}\right), 28.5\left(\mathrm{CH}_{2}\right), 53.5\left(\mathrm{OCH}_{3}\right), 128.3$ $(\mathrm{CH}), 130.5(\mathrm{C}), 130.6(\mathrm{CH}), 131.3(\mathrm{CH}), 131.8(\mathrm{CH}), 133.7(\mathrm{C}), 134.1(\mathrm{C}), 138.8(=\mathrm{CH}), 152.6$ (C), 167.4 (C), 169.8 (C), 180.9 (C); Anal. Calcd for $\mathrm{C}_{16} \mathrm{H}_{17} \mathrm{ClN}_{2} \mathrm{O}_{4} \mathrm{~S}$ (\%): C, 52.10; H, 4.65; N, 7.60; S, 8.69. Found: C, 52.47; H, 4.64; N, 7.56; S, 8.58.

Methyl (Z)-3-(2-naphthyl)-2-[( $N, N^{\prime}$-diacetylisothioureido)methyl]-2-propenoate (7f). White solid, mp 114.5-116.0 ${ }^{\circ} \mathrm{C}$; IR (KBr) $v_{\max } / \mathrm{cm}^{-1}: 3434,3058,2957,1730,1709,1623,1539,1428$, 1389, 1251, 1210, 1192, 1154, 816; ${ }^{1} \mathrm{H}$ NMR (400 MHz, DMSO- $\left.d_{6}\right): \delta 1.73$ (s, 3H), 1.96 (s, 3H), 3.79 (s, 3H), 4.14 (s, 2H), 7.50-7.65 (m, 3H), 7.89-8.00 (m, 4H), 8.06 (s, 1H), 10.97 (brs, 1H); ${ }^{13} \mathrm{C}$ NMR (100 MHz, DMSO-d $): \delta 24.4\left(\mathrm{CH}_{3}\right), 26.8\left(\mathrm{CH}_{3}\right), 29.1\left(\mathrm{CH}_{2}\right), 53.4\left(\mathrm{OCH}_{3}\right), 127.6$ $(\mathrm{CH}), 127.7(\mathrm{CH}), 127.8(\mathrm{C}), 128.3(\mathrm{CH}), 128.5(\mathrm{CH}), 129.2(\mathrm{CH}), 129.4(\mathrm{CH}), 130.8(\mathrm{CH})$, 132.8 (C), 133.6 (C), 133.9 (C), 142.5 (=CH), 153.0 (C), 167.9 (C), 169.8 (C), 181.0 (C); Anal. Calcd for $\mathrm{C}_{20} \mathrm{H}_{20} \mathrm{~N}_{2} \mathrm{O}_{4} \mathrm{~S}(\%)$ : C, 62.48; H, 5.24; N, 7.29; S, 8.34. Found: C, 62.63; H, 5.29; N, $7.21 ; \mathrm{S}, 8.19$.

Methyl (Z)-2-[( $N, N^{\prime}$-diacetylisothioureido)methyl]-2-butenoate (7g). Clear yellow oil, IR (neat) $v_{\max } / \mathrm{cm}^{-1}: 3002,2952,1717,1628,1544,1435,1384,1267,1213,1191 ;{ }^{1} \mathrm{H}$ NMR (400 MHz, DMSO- $\left.d_{6}\right): \delta 1.87(\mathrm{~d}, J=7.2 \mathrm{~Hz}, 3 \mathrm{H}), 1.97(\mathrm{~s}, 3 \mathrm{H}), 2.08(\mathrm{~s}, 3 \mathrm{H}), 3.67$ (s, 3H), 3.80 (s, 2H), 6.90 (q, $J=7.2 \mathrm{~Hz}, 1 \mathrm{H}), 10.93$ (brs, $1 \mathrm{H}) ;{ }^{13} \mathrm{C}$ NMR (100 MHz, DMSO-d $\left.)\right): \delta 15.6\left(\mathrm{CH}_{3}\right)$, $24.4\left(\mathrm{CH}_{3}\right), 27.3\left(\mathrm{CH}_{3}\right), 27.4\left(\mathrm{CH}_{2}\right), 52.9\left(\mathrm{CH}_{3}\right), 128.8(\mathrm{C}), 142.6(=\mathrm{CH}), 153.2(\mathrm{C}), 167.3(\mathrm{C})$, $169.8(\mathrm{C}), 181.1(\mathrm{C})$.

Methyl (Z)-2-[( $N, N^{\prime}$-diacetylisothioureido)methyl]-2-pentenoate (7h). Clear yellow oil, IR (neat) $v_{\max } / \mathrm{cm}^{-1}: 3288,2963,2873,1718,1625,1545,1437,1384,1365,1256,1213,1194 ;{ }^{1} \mathrm{H}$ NMR (400 MHz, DMSO-d6): $\delta 0.98$ (t, $J=7.4$ Hz, 3H), 1.98 (brs, 3H), 2.07 (brs, 3H), 2.28 (dq, $J=7.4$ and $7.8 \mathrm{~Hz}, 2 \mathrm{H}), 3.67(\mathrm{~s}, 3 \mathrm{H}), 3.79(\mathrm{~s}, 2 \mathrm{H}), 6.79(\mathrm{t}, J=7.8 \mathrm{~Hz}, 1 \mathrm{H}), 10.94(\mathrm{brs}, 1 \mathrm{H}) ;{ }^{13} \mathrm{C}$ NMR (100 MHz, DMSO-d $): \delta 14.0\left(\mathrm{CH}_{3}\right), 22.9\left(\mathrm{CH}_{2}\right), 24.4\left(\mathrm{CH}_{3}\right), 27.3\left(\mathrm{CH}_{3}\right), 27.5\left(\mathrm{CH}_{2}\right)$, $52.9\left(\mathrm{CH}_{3}\right), 127.4(\mathrm{C}), 148.8(=\mathrm{CH}), 153.4(\mathrm{C}), 167.4(\mathrm{C}), 169.8(\mathrm{C}), 181.2(\mathrm{C})$.

\section{Typical procedure for the acetylation of isothiuronium bromides (6)}

To a stirred suspension of the isothiuronium bromide $6(1.0 \mathrm{mmol})$ in $3.0 \mathrm{~mL}$ of $\mathrm{CH}_{2} \mathrm{Cl}_{2}$ at $25^{\circ} \mathrm{C}$ was added acetic anhydride $(3.0 \mathrm{mmol})$ followed by sat. $\mathrm{NaHCO}_{3}(3.0 \mathrm{~mL})$. After stirring for 20 min, the final mixture was diluted with $\mathrm{CH}_{2} \mathrm{Cl}_{2}$ and the organic extract was washed with $\mathrm{H}_{2} \mathrm{O}$ 
and brine, dried over $\mathrm{Na}_{2} \mathrm{SO}_{4}$, filtered and concentrated under reduced pressure. The resulting residue was purified by recrystallization with ethyl acetate to give the corresponding products $\mathbf{1 0}$. Methyl ( $Z$ )-2-[( $N$-acetyl- $N^{\prime}$-phenylisothioureido)methyl]-3-(4-methoxyphenyl)-2-propenoate (10b). White solid, mp 153.5-155.0 ${ }^{\circ} \mathrm{C}$; IR (KBr) $v_{\max } / \mathrm{cm}^{-1}: 3445,3244,2997,2947,2835,1717$, 1692, 1600, 1513, 1435, 1273, 1256, 1222, 1177, 1160, 1077; ${ }^{1} \mathrm{H}$ NMR (400 MHz, DMSO- $\left.d_{6}\right): \delta$ $1.88(\mathrm{~s}, 3 \mathrm{H}), 3.73(\mathrm{~s}, 3 \mathrm{H}), 3.77(\mathrm{~s}, 3 \mathrm{H}), 4.07$ (s, 2H), 6.78 (d, $J=7.5 \mathrm{~Hz}, 2 \mathrm{H}), 6.98-7.03$ (m, 3H), 7.27 (t, $J=7.5 \mathrm{~Hz}, 2 \mathrm{H}), 7.53$ (brs, 2H), 7.67 (s, 1H), 9.87 (brs, NH); ${ }^{13} \mathrm{C} \mathrm{NMR} \mathrm{(100} \mathrm{MHz,}$ DMSO-d $): \delta 23.9\left(\mathrm{CH}_{3}\right), 30.1\left(\mathrm{CH}_{2}\right), 53.2\left(\mathrm{OCH}_{3}\right), 56.3\left(\mathrm{OCH}_{3}\right), 115.3(2 \mathrm{x} \mathrm{CH}), 121.6(2 \mathrm{x}$ $\mathrm{CH}), 124.4(\mathrm{CH}), 124.8(\mathrm{C}), 127.4(\mathrm{C}), 129.9$ (2 x CH), 132.9 (2 x CH), $142.4(=\mathrm{CH}), 148.7$ (C), 151.3 (C), 161.3 (C), 168.1 (C), 169.8 (C); Anal. Calcd. for $\mathrm{C}_{21} \mathrm{H}_{22} \mathrm{~N}_{2} \mathrm{O}_{4} \mathrm{~S}$ (\%): C, 63.30; H, 5.56; N, 7.03; S, 8.05. Found: C, 62.82; H, 5.60; N, 6.69; S, 7.76.

Methyl (Z)-2-[( $N$-acetyl- $N$ '-phenylisothioureido)methyl]-3-(4-nitrophenyl)-2-propenoate (10d). Yellow solid, mp 135.5-137.0 ${ }^{\circ} \mathrm{C}$; IR $(\mathrm{KBr}) v_{\max } / \mathrm{cm}^{-1}$ : 3445, 3356, 3058, 2998, 2952 , $1717,1706,1610,1593,1587,1519,1345,1258,1242,1160,1080 ;{ }^{1} \mathrm{H}$ NMR (400 MHz, DMSO-d $\left.d_{6}\right) \delta 1.83(\mathrm{~s}, 3 \mathrm{H}), 3.77(\mathrm{~s}, 3 \mathrm{H}), 4.09(\mathrm{~s}, 2 \mathrm{H}), 6.60$ (brs, 2H), $6.97(\mathrm{t}, J=7.5 \mathrm{~Hz}, 1 \mathrm{H})$, 7.19 (t, $J=7.5 \mathrm{~Hz}, 2 \mathrm{H}), 7.72$ (d, $J=8.5 \mathrm{~Hz}, 2 \mathrm{H}), 7.76$ (s, 1H), 8.14 (brs, 2H), 9.81 (brs, NH); ${ }^{13} \mathrm{C}$ NMR (100 MHz, DMSO-d $): \delta 23.9\left(\mathrm{CH}_{3}\right), 29.0\left(\mathrm{CH}_{2}\right), 53.5\left(\mathrm{OCH}_{3}\right), 121.5(2 \times \mathrm{CH}), 124.4$ $(\mathrm{CH}), 124.5(2 \times \mathrm{CH}), 129.7(2 \times \mathrm{CH}), 129.8(\mathrm{C}), 131.5(2 \times \mathrm{CH}), 139.5(=\mathrm{CH}), 142.0(\mathrm{C}), 148.1$ (C), 148.3 (C), 150.5 (C), 167.6 (C), 169.6 (C); Anal. Calcd. for $\mathrm{C}_{20} \mathrm{H}_{19} \mathrm{~N}_{3} \mathrm{O}_{5} \mathrm{~S}$ (\%): C, 58.10; $\mathrm{H}$, 4.63; N, 10.16; S, 7.76. Found: C, 58.47; H, 4.69; N, 10.10; S, 7.63.

Methyl 3-( $N$-acetyl- $N$-phenylthioureido)-2-methylene-3-(4-nitrophenyl)propanoate (11d). To a stirred suspension of the isothiuronium bromide $\mathbf{6 d}(1.0 \mathrm{mmol})$ in $3.0 \mathrm{~mL}$ of $\mathrm{CH}_{2} \mathrm{Cl}_{2}$ at 25 ${ }^{\circ} \mathrm{C}$ was added acetic anhydride $(3.0 \mathrm{mmol})$ followed by sat. $\mathrm{NaHCO}_{3}(3.0 \mathrm{~mL})$. After stirring for 15 days, the resulting mixture was diluted with $\mathrm{CH}_{2} \mathrm{Cl}_{2}$ and the organic extract was washed with $\mathrm{H}_{2} \mathrm{O}$ and brine, dried over $\mathrm{Na}_{2} \mathrm{SO}_{4}$, filtered and concentrated under reduced pressure. The final residue was submitted to chromatography ( $4: 1$ hexanes/EtOAc) to give the monoacetyl product 10d (63\% yield) and the rearranged adduct 11d as a pale yellow oil (31\% yield); IR (neat) $\nu_{\max } / \mathrm{cm}^{-1}: 3339,3204,3120,2947,2924,1721,1681,1596,1520,1492,1348,1252,1108 ;{ }^{1} \mathrm{H}$ NMR (400 MHz, $\left.\mathrm{CDCl}_{3}\right): \delta 1.99(\mathrm{~s}, 3 \mathrm{H}), 3.74(\mathrm{~s}, 3 \mathrm{H}), 6.12(\mathrm{~s}, 1 \mathrm{H}), 6.51(\mathrm{~s}, 1 \mathrm{H}), 6.78(\mathrm{~d}, J=8.4$ $\mathrm{Hz}, 1 \mathrm{H}), 7.23-7.25(\mathrm{~m}, 2 \mathrm{H}), 7.44-7.50(\mathrm{~m}, 3 \mathrm{H}), 7.55(\mathrm{~d}, J=8.7 \mathrm{~Hz}, 2 \mathrm{H}), 8.21(\mathrm{~d}, J=8.7 \mathrm{~Hz}$, $2 \mathrm{H}), 12.64\left(\mathrm{~d}, J=8.4 \mathrm{~Hz}, 1 \mathrm{H}, \mathrm{D}_{2} \mathrm{O}\right.$ exchange); ${ }^{13} \mathrm{C} \mathrm{NMR}\left(100 \mathrm{MHz}, \mathrm{CDCl}_{3}\right): \delta 28.3\left(\mathrm{CH}_{3}\right), 52.7$ $\left(\mathrm{OCH}_{3}\right), 61.7(\mathrm{CH}), 124.2(2 \times \mathrm{CH}), 127.9(2 \times \mathrm{CH}), 129.4(\mathrm{CH}), 129.9(4 \times \mathrm{CH}), 130.0\left(=\mathrm{CH}_{2}\right)$, 137.8 (C), 142.4 (C), 146.4 (C), 147.6 (C), 165.8 (C), 175.5 (C), 184.3 (C).

\section{Synthesis of 2-amino-1,3-thiazin-4-ones (3)}

From the allylic bromides (2). To a stirred solution of allylic bromide $2(1.0 \mathrm{mmol})$ in $4.0 \mathrm{~mL}$ of acetone $/ \mathrm{H}_{2} \mathrm{O}(3: 1 \mathrm{v} / \mathrm{v})$ at $25{ }^{\circ} \mathrm{C}$ was added $2.0 \mathrm{mmol}$ of thiourea. After stirring for $1-3 \mathrm{~h}$, the final mixture was extracted with $\mathrm{CH}_{2} \mathrm{Cl}_{2}$ and the organic extract was discarded. The aqueous phase was then treated with $5.0 \mathrm{~mL}$ of sat. $\mathrm{NaHCO}_{3}$ and the remaining basic solution was immediately extracted with $\mathrm{CH}_{2} \mathrm{Cl}_{2}$. The organic extract was concentrated under reduced 
pressure and the resulting solid was washed with $\mathrm{H}_{2} \mathrm{O}$, EtOH and acetone to give the corresponding 2-amino-1,3-thiazin-4-one 3.

From the isothiuronium bromides (5). To a stirred suspension of isothiuronium salt 5 (1.0 $\mathrm{mmol})$ in $3.0 \mathrm{~mL}$ of $\mathrm{CH}_{2} \mathrm{Cl}_{2}$ was added sat. $\mathrm{NaHCO}_{3}(3.0 \mathrm{~mL})$. After stirring for $15 \mathrm{~min}$, the final mixture was diluted with $\mathrm{CH}_{2} \mathrm{Cl}_{2}$ and the organic extract was washed with $\mathrm{H}_{2} \mathrm{O}$ and concentrated under reduced pressure. The solid formed was crushed with $\mathrm{CH}_{2} \mathrm{Cl}_{2}$ and filtrated to give the corresponding thiazin-4-one 3 .

(5Z)-2-Amino-5,6-dihydro-[5-(4-methoxybenzylidene)]-1,3-thiazin-4-one (3b). White solid, mp 199.5-201.0 ${ }^{\circ} \mathrm{C}$; IR (KBr) $v_{\max } / \mathrm{cm}^{-1}: 3257,2971,1636,1588,1503,1308 ;{ }^{1} \mathrm{H}$ NMR (400 MHz, TFA- $d_{1}, \mathrm{C}_{6} \mathrm{D}_{6}$ as internal standard): $\delta 4.33$ (s, 3H), $4.82(\mathrm{~s}, 2 \mathrm{H}), 7.47(\mathrm{~d}, J=8.8 \mathrm{~Hz}, 2 \mathrm{H})$, $7.81(\mathrm{~d}, J=8.8 \mathrm{~Hz}, 2 \mathrm{H}), 8.50(\mathrm{~s}, 1 \mathrm{H}) ;{ }^{13} \mathrm{C} \mathrm{NMR}\left(100 \mathrm{MHz}, \mathrm{TFA}-d_{1}, \mathrm{C}_{6} \mathrm{D}_{6}\right.$ as internal standard): $\delta$ 26.0, 55.4, 115.2, 116.4, 126.5, 132.8, 148.9, 161.8, 166.4, 174.2; Anal. Calcd. for $\mathrm{C}_{12} \mathrm{H}_{12} \mathrm{~N}_{2} \mathrm{O}_{2} \mathrm{~S}$ : C, 58.05; H, 4.87; N, 11.28; S, 12.91. Found: C, 57.88; H, 5.00; N, 11.41; S, 12.85 .

(5Z)-2-Amino-5,6-dihydro-[5-(3,4-methylenedioxybenzylidene)]-1,3-thiazin-4-one (3c). Yellow solid, mp 208.0-210.0 ${ }^{\circ} \mathrm{C}$; IR (KBr) $v_{\max } / \mathrm{cm}^{-1}: 3279,2894,1641,1595,1491,1309 ;{ }^{1} \mathrm{H}$ NMR (400 MHz, TFA- $d_{1}, \mathrm{C}_{6} \mathrm{D}_{6}$ as internal standard): $\delta 4.76(\mathrm{~s}, 2 \mathrm{H}), 6.32(\mathrm{~s}, 2 \mathrm{H}), 7.20-7.35$ (m, $3 \mathrm{H}), 8.37(\mathrm{~s}, 1 \mathrm{H}) ;{ }^{13} \mathrm{C}$ NMR $\left(100 \mathrm{MHz}, \mathrm{TFA}-d_{1}, \mathrm{C}_{6} \mathrm{D}_{6}\right.$ as internal standard): $\delta 26.0,102.3,109.4$, 109.7, 116.4, 127.0, 127.1, 148.7, 148.9, 151.1, 166.2, 174.2; Anal. Calcd. for $\mathrm{C}_{12} \mathrm{H}_{10} \mathrm{~N}_{2} \mathrm{O}_{3} \mathrm{~S}$ : C, 54.95; H, 3.84; N, 10.68; S, 12.23. Found: C, 54.72; H, 3.71; N, 10.47; S, 12.57.

(5Z)-2-Amino-5,6-dihydro-[5-(4-nitrobenzylidene)]-1,3-thiazin-4-one (3d). Yellow solid, mp 232.0-235.0 ${ }^{\circ} \mathrm{C}$; IR (KBr) $v_{\max } / \mathrm{cm}^{-1}: 3256,2944,1635,1589,1504,1308 ;{ }^{1} \mathrm{H}$ NMR (400 MHz, TFA- $d_{1}, \mathrm{C}_{6} \mathrm{D}_{6}$ as internal standard): $\delta 4.60(\mathrm{~s}, 2 \mathrm{H}), 7.85(\mathrm{~d}, J=8.5 \mathrm{~Hz}, 2 \mathrm{H}), 8.41(\mathrm{~s}, 1 \mathrm{H}), 8.61(\mathrm{~d}$, $J=8.5 \mathrm{~Hz}, 2 \mathrm{H}) ;{ }^{13} \mathrm{C} \mathrm{NMR}\left(100 \mathrm{MHz}, \mathrm{TFA}-d_{1}, \mathrm{C}_{6} \mathrm{D}_{6}\right.$ as internal standard): $\delta 25.5,123.0,124.5$, 130.5, 139.6, 144.4, 148.6, 164.7, 174.0; Anal. Calcd. for $\mathrm{C}_{11} \mathrm{H}_{9} \mathrm{~N}_{3} \mathrm{O}_{3} \mathrm{~S}: \mathrm{C}, 50.18 ; \mathrm{H}, 3.45 ; \mathrm{N}$, 15.96; S, 12.18. Found: C, 49.85; H, 3.42; N, 15.90; S, 11.86.

(5Z)-2-Amino-5,6-dihydro-[5-(2-nitrobenzylidene)]-1,3-thiazin-4-one (3e). Yellow solid, mp 219.5-220.5 ${ }^{\circ} \mathrm{C}$; IR (KBr) $\nu_{\max } / \mathrm{cm}^{-1}: 3272,2972,1648,1614,1523,1490,1343,1313 ;{ }^{1} \mathrm{H}$ NMR (400 MHz, TFA- $d_{1}, \mathrm{C}_{6} \mathrm{D}_{6}$ as internal standard): $\delta 4.51(\mathrm{~s}, 2 \mathrm{H}), 7.75(\mathrm{~d}, J=8.0 \mathrm{~Hz}, 1 \mathrm{H}), 8.08(\mathrm{t}, J$ $=8.0 \mathrm{~Hz}, 1 \mathrm{H}), 8.21(\mathrm{t}, J=8.0 \mathrm{~Hz}, 1 \mathrm{H}), 8.72(\mathrm{~d}, J=8.0 \mathrm{~Hz}, 1 \mathrm{H}), 8.76(\mathrm{~s}, 1 \mathrm{H}) ;{ }^{13} \mathrm{C} \mathrm{NMR}(100$ $\mathrm{MHz}, \mathrm{TFA}-d_{1}, \mathrm{C}_{6} \mathrm{D}_{6}$ as internal standard): $\delta 25.8,121.1,126.2,129.0,130.4,131.9,135.6$, 145.1, 147.1, 165.1, 174.4; Anal. Calcd. for $\mathrm{C}_{11} \mathrm{H}_{9} \mathrm{~N}_{3} \mathrm{O}_{3} \mathrm{~S}: \mathrm{C}, 50.18 ; \mathrm{H}, 3.45 ; \mathrm{N}, 15.96 ; \mathrm{S}, 12.18$. Found: C, 49.75; H, 3.43; N, 15.73; S, 12.48 .

(5Z)-2-Amino-[5-(2-chlorobenzylidene)]-5,6-dihydro-1,3-thiazin-4-one (3f). White solid, mp 213.0-214.5 ${ }^{\circ} \mathrm{C}$; IR (KBr) $v_{\max } / \mathrm{cm}^{-1}: 3286,2968,1645,1611,1475,1318 ;{ }^{1} \mathrm{H}$ NMR (400 MHz, TFA- $d_{1}, \mathrm{C}_{6} \mathrm{D}_{6}$ as internal standard): $\delta 4.61(\mathrm{~s}, 2 \mathrm{H}), 7.60(\mathrm{~d}, J=7.5 \mathrm{~Hz}, 1 \mathrm{H}), 7.70-7.80(\mathrm{~m}, 2 \mathrm{H})$, $7.86(\mathrm{~d}, J=8.0 \mathrm{~Hz}, 1 \mathrm{H}), 8.59(\mathrm{~s}, 1 \mathrm{H}) ;{ }^{13} \mathrm{C} \mathrm{NMR}\left(100 \mathrm{MHz}, \mathrm{TFA}-d_{1}, \mathrm{C}_{6} \mathrm{D}_{6}\right.$ as internal standard): $\delta$ 26.0, 121.1, 127.4, 129.8, 130.6, 131.0, 132.5, 134.9, 145.6, 165.5, 174.4; Anal. Calcd. for $\mathrm{C}_{11} \mathrm{H}_{9} \mathrm{ClN}_{2} \mathrm{OS}$ : C, 52.28; H, 3.59; N, 11.08; S, 12.69. Found: C, 51.92; H, 3.46; N, 11.44; S, 12.77 . 
(5Z)-2-Amino-[5-(2,4-dichlorobenzylidene)]-5,6-dihydro-1,3-thiazin-4-one (3h). White solid, mp 204.5-206.5 ${ }^{\circ} \mathrm{C}$; IR (KBr) $v_{\max } / \mathrm{cm}^{-1}: 3294,2954,1636,1603,1481,1306 ;{ }^{1} \mathrm{H}$ NMR (400 $\mathrm{MHz}$, TFA- $d_{1}, \mathrm{C}_{6} \mathrm{D}_{6}$ as internal standard): $\delta 4.61(\mathrm{~s}, 2 \mathrm{H}), 7.57(\mathrm{~d}, J=8.8 \mathrm{~Hz}, 1 \mathrm{H}), 7.74(\mathrm{dd}, J=$ $8.8 \mathrm{~Hz}$ and $1.6 \mathrm{~Hz}, 1 \mathrm{H}), 7.90(\mathrm{~d}, J=1.6 \mathrm{~Hz}, 1 \mathrm{H}), 8.53(\mathrm{~s}, 1 \mathrm{H}) ;{ }^{13} \mathrm{C}$ NMR $\left(100 \mathrm{MHz}, \mathrm{TFA}-d_{l}\right.$, $\mathrm{C}_{6} \mathrm{D}_{6}$ as internal standard): $\delta 26.0,121.8,127.9,129.5,130.6,130.7,135.8,138.7,144.1,165.3$, 174.2; Anal. Calcd. for $\mathrm{C}_{11} \mathrm{H}_{8} \mathrm{Cl}_{2} \mathrm{~N}_{2} \mathrm{OS}$ : C, 46.01; H, 2.81; N, 9.76; S, 11.17. Found: C, 45.72; $\mathrm{H}$, $2.38 ; \mathrm{N}, 9.47 ; \mathrm{S}, 10.91$.

(5Z)-2-Amino-5,6-dihydro-5-[(naphthalen-2-yl)methylene]-1,3-thiazin-4-one (3i). White solid, mp 183.5-186.0 ${ }^{\circ} \mathrm{C}$; IR (KBr) $v_{\max } / \mathrm{cm}^{-1}$ : 3293, 2992, 1639, 1600, 1489, 1302; ${ }^{1} \mathrm{H}$ NMR (400 MHz, TFA- $d_{1}, \mathrm{C}_{6} \mathrm{D}_{6}$ as internal standard): $\delta 4.74(\mathrm{~s}, 2 \mathrm{H}), 7.65-8.20(\mathrm{~m}, 7 \mathrm{H}), 8.54(\mathrm{~s}, 1 \mathrm{H})$; ${ }^{13} \mathrm{C}$ NMR (100 MHz, TFA- $d_{1}, \mathrm{C}_{6} \mathrm{D}_{6}$ as internal standard): $\delta$ 26.0, 118.3, 125.4, 127.6, 127.7, 127.9, 128.7, 129.4, 129.9, 131.6, 133.3, 134.8, 149.2, 166.0, 174.1; Anal. Calcd. for $\mathrm{C}_{15} \mathrm{H}_{12} \mathrm{~N}_{2} \mathrm{OS}$ : C, 67.14; H, 4.51; N, 10.44; S, 11.95. Found: C, 66.79; H, 4.28; N, 10.34; S, 11.78.

\section{Supplementary Material}

Full crystallographic tables for compounds $\mathbf{5 b}, \mathbf{7 b}, \mathbf{1 0 b}$ and $\mathbf{1 0 d}$ have been deposited with the Cambridge Crystallographic Data Centre as supplementary publication number CCDC 772863 (5b), CCDC 772864 (7b), CCDC 772865 (10b) and CCDC 772866 (10d). Copies of the data can be obtained, free of charge, on application to CCDC, 12 Union Road, Cambridge CB2 1EZ, UK [fax: +44 (0) 1223336033 or e-mail: deposit@ ccdc.cam.ac.uk].

\section{Acknowledgements}

The authors wish to thank Central de Análises (Departamento de Química, UFSC, Florianópolis) for spectroscopic analysis. L.F. and M.F. are grateful to CAPES and CNPq (Brazil) for fellowships. M.M.S., A.J.B. and S.C. are grateful to CNPq for research fellowships. Financial support by INCT-Catálise/CNPq (Brazilian Research Council), FAPESC (Santa Catarina State Research Council) and PRONEX-2003 (CNPq/FAPESC) is also gratefully acknowledged.

\section{References}

1. Zhang, G.; Jin, W.; Fukushima, T.; Kosaka, A.; Ishii, N.; Aida, T. J. Am. Chem. Soc. 2007, $129,719$.

2. Shirota, F. N.; Stevens-Johnk, J. N.; DeMaster, E. G.; Nagasawa, H. T. J. Med. Chem. 1997, 40, 1870. 
3. Allan, R. D.; Dickenson, H. W.; Johnston, G. A. R.; Kazlauskas, R.; Mewett, K. N. Neurochem. Int. 1997, 30, 583.

4. Regan, B. M.; Galysh, F. T.; Morris, R. N. J. Med. Chem. 1967, 10, 649.

5. Ouyang, M.; Remy, J.-S.; Szoka, F. C., Jr. Bioconjug. Chem. 2000, 11, 104.

6. Minami, T.; Kaneko, K.; Nagasaki, T.; Kubo, Y. Tetrahedron Lett. 2008, 49, 432.

7. (a) Orlowska, M.; Mroczkiewicz, M.; Guzow, K.; Ostaszewski, R.; Klonkowski, A. M. Tetrahedron 2010, 66, 2486. (b) Nguyen, Q. P. B.; Kim, J. N.; Kim, T. H. Bull. Korean Chem. Soc. 2009, 30, 2093. (c) Seong, H. R.; Kim, D.-S.; Kim, S.-G.; Choi, H.-J.; Ahn, K. H. Tetrahedron Lett. 2004, 45, 723. (d) Kato, R.; Cui, Y.-Y.; Nishizawa, S.; Yokobori, T.; Teramae, N. Tetrahedron Lett. 2004, 45, 4273. (e) Nishizawa, S.; Cui, Y.-Y.; Minagawa, M.; Morita, K.; Kato, Y.; Taniguchi, S.; Kato, R.; Teramae, N. J. Chem. Soc., Perkin Trans. 2 2002, 866. (f) Yeo, W.-S.; Hong, J.-I. Tetrahedron Lett. 1998, 39, 8137. (g) Donleavy, J. J. J. Am. Chem. Soc. 1936, 58, 1004.

8. (a) Bauer, L.; Welsh, T. L. J. Org. Chem. 1961, 26, 1443. (b) Bunce, R. A.; Peeples, C. J.; Jones, P. B. J. Org. Chem. 1992, 57, 1727. (c) Panchadhayee, R.; Misra, A. K. Arkivoc 2009, (ii), 298.

9. (a) Kabalka, G. W.; Mereddy, A. R. Tetrahedron Lett. 2006, 47, 5171. (b) Gorczynski, M. J.; Leal, R. M.; Mooberry, S. L.; Bushweller, J. H.; Brown, M. L. Bioorg. Med. Chem. 2004, 12, 1029. (c) Ohkubo, M.; Kuno, A.; Nakanishi, I.; Takasugi, H. Chem. Pharm. Bull. 1995, 43, 1497.

10. Shadbolt, R. S. J. Chem. Soc. (C) 1971, 1667.

11. (a) Misra, A. L. J. Org. Chem. 1958, 23, 897. (b) Grishchuk, A. P.; Roslaya, G. I. Chem. Heterocycl. Comp. 1971, 7, 986.

12. (a) Sá, M. M.; Ramos, M. D.; Fernandes, L. Tetrahedron 2006, 62, 11652. (b) Fernandes, L.; Bortoluzzi, A. J.; Sá, M. M. Tetrahedron 2004, 60, 9983. (c) Ferreira, M.; Fernandes, L.; Sá, M. M. J. Braz. Chem. Soc. 2009, 20, 564. (d) Sá, M. M. J. Braz. Chem. Soc. 2003, 14, 1005. (e) Sá, M. M.; Meier, L.; Fernandes, L.; Pergher, S. B. C. Catal. Commun. 2007, 8, 1625.

13. (a) Ciganek, E. Organic Reactions; Wiley: New York, 1997; Vol. 51, pp 201-350. (b) Basavaiah, D.; Rao, A. J.; Satyanarayana, T. Chem. Rev. 2003, 103, 811. (c) Singh, V.; Batra, S.; Tetrahedron 2008, 64, 4511. (d) Declerck, V.; Martinez, J.; Lamaty, F. Chem. Rev. 2009, 109, 1.

14. Sá, M. M.; Fernandes, L.; Ferreira, M.; Bortoluzzi, A. J. Tetrahedron Lett. 2008, 49, 1228.

15. (a) Murru, S.; Singh, C. B.; Kavala, V.; Patel, B. K. Tetrahedron 2008, 64, 1931. (b) Yella, R.; Ghosh, H.; Patel, B. K. Green Chem. 2008, 10, 1307. (c) Singh, C. B.; Murru, S.; Kavala, V.; Patel, B. K. Org Lett. 2006, 8, 5397.

16. For related X-ray studies involving Morita-Baylis-Hillman derivatives, see references $12 \mathrm{~b}$, 14 and also: (a) Bortoluzzi, A. J.; Bisol, T. B.; Sá, M. M. Acta Crystallogr., Sect. E 2009, 65, o198. (b) Bortoluzzi, A. J.; Fernandes, L.; Sá, M. M. Acta Crystallogr., Sect. E 2006, 62, o3391. 
17. (a) Williams, R. M.; Yuan, C.; Lee, V. J.; Chamberland, S. J. Antibiot. 1998, 51, 189. (b) Plano, D.; Sanmartin, C.; Moreno, E.; Prior, C.; Calvo, A.; Palop, J. A. Bioorg. Med. Chem. Lett. 2007, 17, 6853.

18. (a) Tal, D. M.; Karlish, S. J. D. Tetrahedron 1995, 51, 3823. (b) Usova, E. B.; Krapivin, G. D.; Kulnevich, V. G. Chem. Heterocycl. Comp. 1990, 4, 477. (c) Krapivin, G. D.; Usova, E. B.; Kulnevich, V. G. Chem. Heterocycl. Comp. 1988, 5, 573. (d) Radics, U.; Mitzner, E.; Liebscher, J. Z. Chem. 1986, 26, 435.

19. (a) Hitchcock, S. R.; Nora, G. P.; Casper, D. M.; Squire, M. D.; Maroules, C. D.; Ferrence, G. M.; Szczepura, L. F.; Standard, J. M. Tetrahedron 2001, 57, 9789. (b) Casper, D. M.; Blackburn, J. R.; Maroules, C. D.; Brady, T.; Esken, J. M.; Ferrence, G. M.; Standard, J. M.; Hitchcock, S. R. J. Org. Chem. 2002, 67, 8871.

20. Kim, Y. G.; Lim, H. N.; Lee, K. J. J. Heterocycl. Chem. 2009, 46, 23.

21. Cha, M. J.; Song, Y. S.; Lee, K. J. Bull. Korean Chem. Soc. 2006, 27, 1900.

22. (a) Huang, S.; Pan, Y.; Zhu, Y.; Wu, A. Org. Lett. 2005, 7, 3797. (b) Koketsu, M.; Tanaka, K.; Takenaka, Y.; Kwong, C. D.; Ishihara, H. Eur. J. Pharm. Sci. 2002, 15, 307. (c) Tozkoparan, B.; Aktay, G.; Yesilada, E. Il Farmaco 2002, 57, 145. (d) Bózsing, D.; Sohár, P.; Gigler, G.; Kovács, G. Eur. J. Med. Chem. 1996, 31, 663. (e) Cohen, N.; Banner, B. L. J. Heterocycl. Chem. 1977, 14, 717. (f) Barret, G. C.; Kane, V. V.; Lowe, G. J. Chem. Soc. 1964, 783.

23. (a) Yadav, L. D. S.; Rai, V. K.; Yadav, B. S. Tetrahedron 2009, 65, 1306. (b) Yavari, I.; Bayat, M. J.; Souri, S.; Sirouspour, M. Helv. Chim. Acta 2009, 92, 1903. (c) Shestakov, A. S.; Gusakova, N. V.; Shikhaliev, K. S.; Timoshkina, A. G. Russ. J. Org. Chem. 2007, 43, 1825. (d) Britsun, V. N.; Esipenko, A. N.; Lozinskii, M. O. Russ. J. Org. Chem. 2006, 42, 1719.

24. Hanefeld, W. Arch. Pharm. 1977, 310, 273.

25. (a) Cunha, S.; Macedo Jr, F. C.; Costa, G. A. N.; Rodrigues Jr, M. T.; Verde, R. B. V.; Souza Neta, L. C.; Vencato, I.; Lariucci, C.; Sá, F. P. Monatsh. Chem. 2007, 138, 511. (b) Cunha, S.; Rodrigues Jr, M. T. Tetrahedron Lett. 2006, 47, 6955. 